\title{
ORIGEN DIVINO, ESPÍRITU LAICO Y PODER REAL EN LA CASTILLA DEL SIGLO XIII ${ }^{1}$
}

\author{
JOSÉ MANUEL NIETO SORIA \\ Universidad Complutense. Madrid
}

\begin{abstract}
SUMARIO
1. Referencias para el debate historiográfico.- 2. Principios políticos y recursos retóricos: algunos ejemplos.- 3 . El rey como ideal ético-moral. 4. El origen divino de la realeza.- 5 . Origen divino, unción real y monarquía sagrada.- 6. La Iglesia en la estructura política.- 7. Algunos tópicos historiográficos.
\end{abstract}

Desde la sociología histórica, así como en la historiografía del presente siglo, se ha advertido repetidamente la trascendencia que en la evolución de la sociedad occidental ha tenido el concepto de secularización o la idea de expansión del espíritu laico².

\footnotetext{
'Este artículo forma parte del Proyecto de Investigación Multidisciplinar n' 5686/94, financiado por la Universidad Complutense de Madrid, sobre el tema "Propaganda y legitimación en los orígenes de la monarquía hispánica: una visión multidisciplinar".

2"La secularización es la esencia de la modernidad. Es, también, su acicate. Y es, finalmente, su forma de concebir el tiempo. como despliegue continuo de la racionalización y humanización que la noción entraña (...) En todo caso, está claro que toda reflexión sobre el tiempo que quiera incorporar su dimensión sociopolítica tendrá que habérselas frontalmente con la cuestión de la secularización". Salvador GINER, El tiempo del poder: a propósito de la filosofía histórica de Giacomo Marramao, en Giacomo Marramao, "Poder y secularización", Madrid, 1989, p. 10
} 
El concepto de secularización parece haberse convertido en elemento esencial e insustituible de la propia idea de modernidad. No hay que olvidar su carácter de "metáfora". Surgido inicialmente en el contexto de las circunstancias jurídicas de la Reforma para referirse al proceso de expropiación de los bienes eclesiásticos en favor de los príncipes o de las iglesias nacionales reformadas, tendrá lugar su definitiva expansión como concepto no ya sólo jurídico, sino también político, e incluso filosófico, en el trascurso del siglo $\mathrm{XIX}^{3}$. Precisamente esta última circunstancia, la vinculación esencial entre secularización y modernidad, ha favorecido que la trasposición de este problema al análisis de las ideas y de las estructuras políticas en tiempos premodernos haya producido división de opiniones y no haya favorecido el consenso historiográfico sobre su interpretación y aplicabilidad, tal como será posible comprobar más adelante. Tal dificultad de consenso suele, además, agudizarse cuando de lo que se trata no es ya sólo definir una corriente general de pensamiento o de transformación política, sino de analizar una estructura ideológico-política concreta, en un marco temporal preciso.

Se ha señalado en alguna ocasión que "el siglo XIII fue la centuria por excelencia en la que se forjaron las estrategias de construcción estatal y de centralización política"4. Tal argumento otorga particular importancia al problema de las tendencias secularizadoras si se tiene en cuenta la frecuente remisión, precisamente al siglo XIII, de la presencia de indicios secularizadores significacivos, lo que inclina a sospechar la posible conexión entre tales indicios secularizadores y esa forja de "estrategias de construcción estatal y de centralización política". Por otra parte, el propio carácter inicial de ese contexto cronológico para la cuestión aquí tratada ya implica la imposibilidad de constatación de su éxito evidente en el escenario temporal elegido, por lo que su presencia siempre hay que relativizarla por la constatación de lo que podría valorarse como supervivencias adversas en forma de fenómenos sacralizadores, quedando así planteado en términos genéricos uno de los procesos más caracterizadores de la evolución final de los tiempos medievales. Tal relación dialéctica se hace particularmente

\footnotetext{
${ }^{3}$ Amplia información bibliográfica sobre el origen del concepto de secularización, sobre todo en sus acepciones sociológica, política y filosófica, y su evolución histórica hasta la actualidad es Giacomo Marramao, Poder y secularización, Madrid, 1989, p. 253, nota 1.

${ }^{4} \mathrm{~B}$. BADIE, Le point de lue du politologue, "L'Etat moderne: le droit, l'espace et le pouvoir", ed. N. Coulet y J.Ph. Genet, París, 1990, p. 213.
} 
compleja como consecuencia de su falta de linealidad evolutiva, con continuos retrocesos y avances resultantes de las circunstancias coyunturales que favorecen una opción u otra y que obligan a evitar cualquier forma de rotundidad a la hora de caracterizar el estadio en que se halle la evolución del fenómeno ante la inevitable amenaza de retrocesos más o menos inmediatos y difícilmente previsibles ${ }^{5}$.

El siglo XIII, en particular en su segunda mitad, que será la que reciba aquí atención preferente, puede considerarse en todo el mundo occidental, y también en el castellano, como un periodo particularmente decisivo a la hora de establecer todo un repertorio de recursos propagandísticos, sobre todo en el plano del debate ideológico-político, en forma de imágenes, tópicos y retóricas varias. Ese repertorio va a ser objeto de recurrente utilización y reinterpretación en el trascurso del resto de los tiempos bajomedievales, llegando muchos de sus elementos con no poca vitalidad al comienzo de los tiempos modernos. En su definición, va a desarrollar un papel relevante ese juego entre secularización-sacralización que, sin explicar enteramente la construcción de aquel sistema de representación, sí exige de un análisis específico para su más completa comprensión.

\section{REFERENCIAS PARA EL DEBATE HISTORIOGRÁFICO}

La obra de Georges Lagarde, en particular su primer volumen, marcó ya en 1934 un punto de referencia ineludible en el análisis de lo que en ella se enunciaba en términos de "nacimiento del espíritu laico", remitiendo preferentemente el análisis del origen de tal cuestión al siglo $\mathrm{XIII}^{6}$. Por su carácter sistemático y globalizador - bien que con total ausencia a referencias peninsulares-, a pesar del tiempo transcurrido desde la primera edición, más de seis décadas, cualquier aproximación a este

\footnotetext{
${ }^{5}$ En este sentido, hay que observar cómo, a lo largo de toda la Baja Edad Media, el realineamiento entre tendencias secularizadoras y sacralizadoras constituye una dimensión típica de los procesos de confrontación política en los que tienen lugar fenómenos relevantes de crisis de legitimidad, bien por la debilidad del poder monárquico, o bien por sus nuevas pretensiones de control. Es así que no será de extrañar que en momentos tardíos, tal como en el siglo XV, tengan lugar nuevas expresiones de resacralización, aunque, para ser correctamente entendidas, será conveniente, tal como se hará más adelante, establecer algunas cautelas con respecto al propio concepto de sacralización.

${ }^{6}$ Georges de LAGARDE, La naissance de l'esprit laïque au déclin du moyen age, 5 vols., París, 1934. En adelante, se citará por la reimpresión de 1973 de la tercera edición de 1956.
} 
problema debe remitirse como punto de partida a lo allí planteado, bien sea para corroborar las interpretaciones propuestas o para establecer correcciones a las mismas. Algunos de sus puntos de vista habrán de retomarse ahora para ser tenidos en cuenta en el análisis de las cuestiones que haya de desarrollarse más adelante.

El espíritu laico era entendido en esta obra como el conjunto de tendencias que progresivamente favorecieron en todos los planos de la vida occidental una relación de alteridad, cuando no de oposición, entre el clérigo y el laico, llevando a los laicos a tomar conciencia de su solidaridad para reivindicar plena soberanía, tanto en la Iglesia como en el Estado, en la actividad intelectual ${ }^{7}$, como en el orden político ${ }^{8}$.

Esta relación de oposición o, por ser más neutral, de alteridad, tan directa entre clérigos y laicos se ha percibido en algunas manifestaciones de la historiografía reciente como excesivamente simplificadora y, por ello, falseadora de la realidad ${ }^{9}$. Así, se ha propuesto superar lo que se consideran problemas demasiado anticuados en su planteamiento ${ }^{10}$, como el de concebir la construcción del Estado como resultante del proceso de

${ }^{7}$ Precisamente en el plano de la actividad intelectual el problema del impulso del espíritu laico ha incorporado en la historiografía recientes nuevas líneas de investigación, como, por ejemplo, la que se refiere a su relación con la emergencia del individualismo, tan presente en una amplia variedad de textos entre los siglos XII al XIV, tal como ha puesto de relieve Janet COLEman, The Individual and the Medieval State, en "The Individual in political Theory and Practice", edic. de J. Coleman, Oxford, 1996, pp. 1-34.

${ }^{8}$ Ibid., I, p. XI.

'Jacques CHIFFOLEAU y Bernard VINCENT, Etat et Eglise dans la genèse de l'État Moderne. Premier bilan, en "État et Église dans la genèse de IÉtat moderne", ed. de J.-Ph. Genet y B. Vincent, Madrid, 1986, pp. 308-309.

${ }^{10}$ Jacques Le Goff, con relación al caso particular de la monarquía capeta, ha calificado como de anacrónica la valoración de unas tendencias secularizadoras en la evolución experimentada por la monarquía francesa. Jacques LE GoFF, Aspects religieux et sacrés de la monarchie française du $X^{\prime \prime}$ au XIII" siècle, en "La royauté sacrée dans le monde chrétien", ed. de A. Boureau y C.-S. Ingerflon, París, 1992, pp. 19-28, en particular, p. 27. Independientemente de la ya aludida modernidad del término "secularización", si lo que por ella entendemos no es solamente la sustitución de referencias de origen religioso bajo la administración monopolizadora de la Iglesia por otras de origen laico, tal como parece plantearlo Le Goff en el trabajo de referencia, sino la permanencia selectiva de esas referencias religiosas, pero bajo el control laico, en concreto de la monarquía, sin necesidad de recurrir a la mediación eclesiástica, creo que su aplicación, en el caso castellano, tal como se verá, podría ser factible para clarificar determinados problemas referentes a la evolución de la ideología política bajomedieval castellana. 
confrontación con la Iglesia" ${ }^{11}$, de manera que, siguiendo la propuesta de Paolo Prodi' ${ }^{12}$, convenga repensar las relaciones Iglesia-Estado como una relación mucho más compleja, en la que tienen lugar mutuas trasferencias e interinfluencias, contribuyendo así a configurarse mutuamente a partir de esos intercambios y no tan sólo por la relación de oposición que propusiera Lagarde. La validez de esta perspectiva crítica que considero muy acertada y que ya he tratado de plasmar con relación al caso concreto castellano ${ }^{13}$, creo que, sin embargo, no impide retener algo de la aportación de Lagarde, me refiero a la constatación histórica de un fenómeno aparentemente contradictorio y cuyo análisis se planteará a lo largo de todo este trabajo como cuestión medular: el que si el Estado no se construye contra la Iglesia, sino, más bien, como consecuencia de un proceso de interacción de componentes muy diversos, en el análisis de tal proceso sí convendrá determinar lo que viene de uno y de otro lado y cómo es objeto de manipulación por cada una de las partes que, si bien tuvieron intereses compartidos, nunca renunciaron a tener otros que les eran particulares a cada una. Con ello, en definitiva, vendría a proponer que ese proceso de repensar las relaciones Iglesia-Estado, si bien no podría quedar limitado a la tradicional relación de oposición, tampoco puede pasar por encima de fenómenos de alteridad que también juegan algún papel en el proceso de mutua transformación ${ }^{14}$.

\footnotetext{
"Pablo FERnÁNDEZ ALBADALejo, Iglesia y configuración del poder en la monarquía católica (siglo XV-XVII). Algunas consideraciones, en "État et Église dans la genèse de l'Etat Moderne", pp. 209-216.

12Paolo Prodi, Il sovrano pontefice. Un corpo e due anime: la monarchia papale nella prima età moderna, Bolonia, 1982.

${ }^{13}$ Así puede verse en mi Iglesia y génesis del Estado moderno en Castilla (1369-1480), Madrid, 1994, en particular, pp. 413-417.

${ }^{14}$ Me parece que a estas alturas de la evolución historiográfica es bastante evidente el aprovechamiento por los poderes monárquicos, en su proceso de crecimiento, del respaldo e influencia de la Iglesia, como el aprovechamiento por la Iglesia de la colaboración y protección de los poderes monárquicos, de tal modo que, a lo largo de todo el Antiguo Régimen, muchos rasgos significativos de su perfil institucional son resultado de tal interacción. Pero ello no debe hacer olvidar que, junto a esa realidad estructural, debe recibir alguna atención aquella otra en la que se plasma la conciencia de una alteridad cuya falta de renocimiento exigiría cerrar los ojos a demasiados testimonios. Es por ello que habrá que conceder alguna atención al problema de la voluntad de autonomía, cuando no de dominio, de los poderes laicos, no sólo el regio, con respecto a los eclesiásticos, sabiendo que esas pretensiones estaban sujetas a una continuada reivindicación cuyo horizonte máximo fue objeto de redefinición en cada época y en cada contexto sociopolítico, en función de sus propias circunstancias y experiencias.
} 
Lagarde señalaba cómo el espíritu laico no puede nacer más que en el seno de una sociedad en la que la distinción entre clérigos y laicos, entre espiritual y temporal, entre autoridad laica y autoridad eclesiástica está netamente marcada. En función de ello, advierte la posibilidad de aplicación de tal concepto al siglo XIII, lo que probablemente ofrecería mayores dificultades para centurias anteriores ${ }^{15}$. No obstante, acaso convenga matizar y de aquí, probablemente, uno de los fundamentos del desacuerdo historiográfico en esta materia, el que no siempre se puede efectuar con la misma nitidez la distinción entre clérigos y laicos, entre espiritual y temporal, en una misma época y en una misma sociedad, y este es el caso - a mi modo de ver- para el siglo XIII. Así lo que se presenta como claramente diferenciado para unas cuestiones, acaso resulte más nebuloso para otras, constatándose seguramente tal hecho, como se verá, de forma particularmente marcada con relación al poder real y a la institución monárquica ${ }^{16}$.

El que sea posible esa distinción, nítida, para Lagarde, parcial y ocasionalmente reconocible, desde mi punto de vista, permite, según el mismo autor, referirse a la idea escolástica de unidad de dominación de los actos como referente inspirador global de lo que fueron las manifestaciones propias del espíritu laico en el contexto del siglo XIII ${ }^{17}$. Aplicado al problema de la realeza, esto habrá de suponer la voluntad de integración para lo que es el ejercicio de sus competencias, siempre en proceso de redefinición, de lo que son aportes ideológicos originales de origen teológico-religioso e instrumentos institucionales y personales de poder de

\footnotetext{
${ }^{15}$ LAGARDE, I, p. 118.

1"Habrá que recordar en este punto otra opinión que viene a marcar la dificultad para aplicar con carácter general, aunque me parece que no tiene por qué ser impedimento para su distinción parcial, esa diferenciación entre laico y eclesiástico o entre sagrado y profano: "La existencia de la Iglesia como mediadora entre Dios y los hombres, legitimadora por la tradición apostólica, impone la consideración de lo sagrado de una manera totalmente diferente. Sin duda, el proyecto totalizante (si no totalitario) de la Iglesia en la sociedad medieval impidió que se desarrollara una esfera de lo profano completamente autónoma", Jean-Claude SCHMITT, La noción de lo sagrado y su aplicación a la historia del cristianismo mediev'al, "Temas Medievales", 3 (Buenos Aires, 1993), pp. 71-81, en particular, p. 74. Si, seguramente, tal como se acaba de afirmar en este fragmento, es necesario tener presente la imposibilidad de completa autonomía de lo profano con respecto a lo sagrado, acaso sí sea posible distinguir niveles intermedios de autonomía, sin perder de vista que, en el plano de lo político, y en el contexto del cristianismo medieval, lo sagrado y lo religioso siempre son variables a valorar (vid. unas precisiones muy básicas al respecto en mi Fundamentos ideológicos del poder real en Castilla (siglos XIII-XVI), Madrid. 1988, pp. 46-48).

${ }^{17}$ Lagarde, I, p. 210.
} 
procedencia eclesiástica, todo ello con la apariencia nueva que ofrece ese criterio de unidad de dominación de los actos bajo el sello real. El seguimiento de la aplicación, unas veces, o del intento de aplicación, otras veces, con relación a la Iglesia o a la religión, puede considerarse, a mi modo de ver, un indicio muy sintómatico, aunque no siempre definitivo, de procesos secularizadores.

En ocasiones, se ha presentado la evolución histórica de las relaciones entre lo político y lo religioso como un progresivo proceso de desacralización, de desencanto del mundo ${ }^{18}$, tal perspectiva, sin embargo, podría resultar demasiado simplificadora si se tiene en cuenta la existencia de procesos de resacralización y de distintas alternativas sacralizadoras cuya apariencia sagrada resulta menos evidente, mucho más sutil, pero políticamente valorable, si se tienen en cuenta sus posibles implicaciones en lo que afecta a las relaciones de poder.

En el marco del siglo XIII, el impulso de la teología tomista supuso el alejamiento respecto de la interpretación agustinista del poder político que tendía a su sacralización al convertirlo en un instrumento al servicio del fin último de la salvación eterna ${ }^{19}$. Visto así, este desplazamiento del agustinismo por el tomismo ${ }^{20}$ podría interpretarse como un episodio típico de ese proceso de desacralización, de desencantamiento. Sin embargo, un acercamiento cauteloso al mensaje tomista podría abrir nuevas perspectivas sacralizadoras del poder público, más directamente controladas por éste mismo, sin una dependencia tan terminante de la mediación eclesiástica tradicional, indispensable en el contexto agustinista, y con unos objetivos

${ }^{18}$ Marcel GAUCHET, Le desenchantement du monde. Une histoire politique de la religion, París, 1985

"Michel Villey, Politique et loi dans la "Somme Théologique" de Thomas d'Aquin, en "L'Etat moderne: le droit, l'espace et les formes de l'état". N. Coulet y J.-Ph. Genet, eds., Paris, 1990, p. 19

${ }^{20}$ Pero sin olvidar que la originalidad del pensamiento tomista consiste en conciliar a Aristóteles con San Agustín, por lo que, a pesar de su novedad con respecto a la tradición agustiniana, la obra política de Santo Tomás no puede entenderse sin tener en cuenta el importante aporte agustiniano: "Digamos ya desde ahora que el pensamiento político de Santo Tomás está inspirado en Aristóteles y en San Agustín. La síntesis de los dos forja su pensamiento e ideología", en Laureano ROBLES y Angel ChUECA, La monarquía de Santo Tomás de Aquino. Madrid, 1994, p. XXXV. Lo interesante, desde el punto de vista de la evolución de la ideología política bajomedieval, es que esa síntesis entre Aristóteles y San Agustín. tal como la desarrolla el Aquinatense, va a permitir elaborar construcciones de interpretación política referentes a la institución monárquica completamente inviables a partir de la exclusiva referencia al pensamiento político agustiniano. 
humanos (el bien común), interpretables, por tanto, por el propio poder público (por ello más susceptibles al debate), pero inspirados también en el concepto de salvación y con unos efectos políticos extraordinarios al permitir aprovechar, ahora en favor de la monarquía, gran parte de la experiencia del sistema sacralizador agustinista aplicado a las relaciones políticas. Es así que, del mismo modo que el bien común, sustituto en el terreno político del concepto de salvación eterna, se convierte en el supremo bien político y en la razón de ser del poder temporal bajo cualquier forma que adopte, la oposición a ese bien común no es tan sólo un delito, sino también un sacrilegio, es decir, un acto contra algo sagrado, lo que, andando el tiempo, aportará nuevos elementos de sacralización del rey, concebido como ministro de Dios elegido para la ejecución del bien común, lo que le otorgará iniciativa de sacrilegización contra todo aquello que se le oponga, aunque para ello tenga que recurrir a la corroboración desde el poder eclesiástico. Así, la función sacralizadora del clero en el marco de las relaciones políticas, con relación a este problema, si no queda, ciertamente, anuladada, sí que se verá relativizada y, en cierto modo, postergada en el proceso lógico del conflicto político, puesto que, si en el contexto ideológico agustinista controlaba todas las claves intepretativas, al ser de la salvación eterna de lo que se juzgaba, ahora ya no posee ese monopolio intepretativo, ya que de lo que se juzga es del bien público, cuyo intérprete natural, en la versión monárquico-autoritaria del tomismo, es el rey.

Problema central que cabe deducir de buena parte de cuanto se lleva dicho es el concepto de sacralidad referido a la esfera de lo político y, en particular, a la caracterización del poder real. Planteada la cuestión en su dimensión puramente teológico-religiosa, lo sacro sólo recibe tal carácter como consecuencia de un acto de consagración cuyos mediadores exclusivos sólo pueden ser los clérigos. De este modo, la distinción del límite entre sagrado y profano no ofrece demasiadas dificultades. Pero no puedo evitar preguntarme, tal como ya se lo han planteado otros autores, si limitar el significado de la idea de sacralidad monárquica a lo que cabe entender como una lógica de orden puramente teológico no supone simplificar lo que tenía implicaciones mucho más complejas ${ }^{21}$. Porque no hay que olvidar que

\footnotetext{
${ }^{21}$ Tal problemática conceptual ya se ha visto proyectada en: Alain BOUREAU y ClaudioSergio INGERFLOM, La royauté sacrée dans le monde chrétien, (Colloque de Royaumont, marzo de 1989). París, 1992. En la historiografía hispánica se ha hecho eco, creo que con gran acierto, de la problemática allí planteada con relación al asunto al que ahora aludo, aplicándola al caso
} 
hablar, en cualquier hipótesis, de la sacralidad de la realeza no deja de ser referirse a una de las manifestaciones más extraordinarias de todo un proceso de manipulación ideológica del que se podían deducir efectos políticos muy variados y que, al menos a fines de la Edad Media, se tenía conciencia, por lo menos en el entorno regio, de esa dimensión manipuladora, lo que tuvo como resultado el impulso de una ideología de la realeza sagrada que no se basaba en ningún acto litúrgico de consagración, pero que pretendía justificar, y de hecho justificó, para quienes quisieran así aceptarlo -entre ellos el propio papa- el carácter de persona sagrada de un rey que no había recibido ninguna forma de consagración litúrgico-eclesiástica ${ }^{22}$. Teniendo en cuenta que, en el plano de la dialéctica política, lo que debe interesar es conocer qué procesos de manipulación se han podido producir para llegar a justificar una posición o una pretensión de poder, me parece inevitable plantear la idea de sacralidad de la realeza en un marco más amplio que el que impone la exigencia de un marco litúrgico de consagración. Este criterio respondería tan sólo a una percepción parcial de las realidades históricas, la que viene impuesta por una lógica de orden teológico-eclesiástico que, por mucha importancia que pudiera tener durante buena parte de la Edad Media, la evolución bajomedieval se encargó de redefinir su papel en el contexto de las relaciones políticas, confrontándola con otras lógicas alternartivas en las que el discurso teológico seguía teniendo su papel, pero en función de unos objetivos políticos que imponían cuantos criterios de manipulación fueran necesarios para evitar contradicciones tan evidentes como la exhibición de sacralidad regia sin pasar por forma alguna de consagración, exigiendo, en cambio, todos los efectos de incontestabilidad que de esta última podía esperar un monarca para sus relaciones con los súbditos.

\footnotetext{
de la realeza aragonesa Bonifacio Palacios Martín, Imágenes y simbolos del poder real en la Corona de Aragón. "El poder real en la Corona de Aragón (siglos XIV-XVI). XV Congreso de Historia de la Corona de Aragón", tomo I. Zaragoza, 1996, en particular, pp. 216-217, en donde. a la vez que recoge algunas de las distintas interpretaciones de la idea de sacralidad regia plasmadas en la obra recién citada, se plantea la pregunta, para la monarquía aragonesa, de " ¿cómo alcanzar la condición de realeza 'sagrada' sin que tal obtención perjudicase a su condición "mayestática"?". Esta es una cuestión que luego plantearé para el caso castellano. Sin embargo, el tratamiento de este problema para la realeza castellana, desarrollado por Peter Linehan (Frontier Kingship: Castile, 1250-1350, "La royauté sacrée", pp. 71-79), a mi modo de ver, no aporta una clarificación satisfactoria del caso castellano al no tener presente toda la complejidad conceptual ni política del problema. No obstante, esta será una cuestión que abordaré más adelante al tratar sobre el tema del origen divino de la realeza en Castilla.

"-Veánse más adelante las referencias alegadas en este sentido para el caso castellano.
} 
Se ha afirmado que la monarquía occidental medieval no ha podido jamás desarrollar una sacralidad propia, de carácter autónomo, pero sí ha podido desarrollar apropiaciones parciales de sacralidad, debiendo ser capaz el historiador de percibir lo que son fórmulas alternativas y niveles diversos de sacralización regia ${ }^{23}$, jugando en cada caso, ciertamente, el factor eclesiástico algún papel, pero no siempre el mismo, ni en un plano comparativo entre monarquías distintas, ni siquiera dentro de una misma monarquía en momentos diferentes ${ }^{24}$.

\footnotetext{
${ }^{23}$ El prof. Palacios, comentando el debate plasmado en La royauté sacrée hace referencia a la posibilidad de distinguir entre una sacralidad plena, más próxima al criterio de un Le Goff, frente a una sacralidad difusa, dibujada por Alain Boureau. PAlacios MARTín, art. cit., nota 94.

${ }^{24}$ Desde esta perspectiva de la interpretación política de la sacralidad regia y su complejidad problemática, me parece oportuno sintetizar algunas reflexiones de Alain Boureau, quien ha señalado cómo la monarquía occidental no ha podido jamás desarrollar una sacralidad propia, autónoma, en razón de su inserción en un sistema jerárquico poderoso que la engloba funcionalmente, cualquiera que sean las circunstancias de las relaciones de fuerza entre la realeza y la Iglesia. Frente al predominio del clero secular sobre lo sagrado, en los siglos XIII y XIV tiene lugar un proceso de multiplicación de jerarquías sagradas que conduce a una polijerarquía que supone la coexistencia concurrente y exclusiva de jerarquías sagradas. En lugar de debilitarse mutuamente, refuerzan el principio de jerarquía sagrada. Esta concurrencia produce interacciones, de modo que la instauración eclesiástica y la designación del fiel como instancia de recepción de lo sagrado se desarrollan en una relación dialéctica de exacerbación mutua. La amplia extensión de la red polijerárquica hace penetrar lo sagrado por todas partes y da fundamento a todas las apropiaciones conflictivas. Un nuevo absoluto, el del Estado, se va perfilando paralelamente, definiéndose por una relación de tensión y de finalidad mutuas entre el Bien Común y el súbdito, pero este absoluto permanece terreste. El Estado se construye por préstamos procedentes del modelo teológico, pero con una trasferencia de la trascendencia hacia la perpetuidad, del cielo hacia la tierra. Entre una captación parcial y controlada de lo sagrado clerical (siglo XIII) y la construcción del absoluto estatal (fin de la Edad Media), la figura real no puede emerger de manera autónoma. Así el monarca puede encontrar un lugar en tal o cual variante de la polijerarquía, pero de manera eminentemente inestable. La autonomía monárquica plena que permita hablar de un verdadero orden monárquico sólo podrá alcanzarse por la proclamación de una neutralidad religiosa que suponga la reactualización de la concepción contractual de la monarquía. Alain BOUREAU, Un obstacle à la sacralité royale en Occident: le principe hiérarchique, en "La royauté sacrée dans le monde chrétien", pp. 2937, en particular, pp. 29 y 33-34. Hay que tener, no obstante, en cuenta que, a partir de fines del siglo XIII, la monarquía estuvo en condiciones lo bastante favorables como para disponer de una gran diversidad de estrategias en sus relaciones con la Iglesia como para asegurarse, en caso de conflicto, el respaldo de alguna parte significativa de la misma, pudiendo tener así la seguridad de una opción sacralizadora para aquellas pretensiones que le conviniesen. Por ello, me parece que, ciertamente, tal como señala Boureau, el monarca estará en condiciones de encontrar un lugar, bajo distintas variantes, dentro de la poliarquía sacralizadora, aunque - tal como indica- de manera inestable, pero que esa inestabilidad no debe referirse tanto a la inseguridad de obtener el respaldo pretendido como a la variación del nivel de la jerarquía en donde éste se halle en cada caso. No hay que olvidar que en los conflictos políticos bajomedievales un rasgo característico de la jerarquía eclesial es que, habitualmente, se dividió como consecuencia del peso que sobre ella ejercían los compromisos extraeclesiales.
} 
Un problema esencial al abordar este tipo de cuestiones es la consideración de los procesos de apropiación de fundamentos teológicos en favor de los nuevos intereses del proyecto monárquico bajomedieval, tal como en muchas monarquías, como en el caso de la castellana, queda enunciado en sus líneas maestras en el trascurso del siglo XIII. El prof. Angel Ferrari apuntó en su día líneas de investigación de gran importancia, todavía hoy insuficientemente exploradas, al señalar el origen teológico de algunas de las principales claves ideológicas e institucionales sobre las que se articuló el poder político en la Castilla bajomedieval ${ }^{25}$ y en el comienzo de los tiempos modernos ${ }^{26}$. Así calificó de método fecundo la teología y la aplicación de sus esquemas más característicos al análisis de la ideología política $^{27}$.

La propia intensificación del proceso de redefinición de las relaciones entre lo político y lo religioso que tuvo lugar en el siglo XIII afectó de lleno a uno de los aspectos esenciales del poder regio, el de la comunicación de sus ideales y pretensiones, en definitiva, el de su propaganda. Precisamente por eso, tal como apuntaba antes, el siglo XIII se convierte en el caso castellano, como ocurre en otras monarquías occidentales, en toda una plataforma de elaboración de recursos propagandísticos de carácter, sobre todo, retórico-literario ${ }^{28}$, en los que el lenguaje religioso se convierte en un vehículo privilegiado ${ }^{29}$, como consecuencia de la intensa actividad de apropiación de referencias teológicas reinterpretadas a la luz de las pretensiones políticas de la realeza ${ }^{30}$. De ahí la ineludible necesidad de

\footnotetext{
${ }^{25}$ Ángel FerRaRI NúÑEz, La secularización de la teoría del Estado en Las Partidas, "Anuario de Historia del Derecho Español", XI (1934), pp. 449-456.

${ }^{26}$ Del mismo autor, Fernando el Católico en Baltasar Gracián, Madrid, 1945.

${ }^{27}$ Ángel FerRaRI NúÑEZ, Medievalismo y teología, "Escorial", 53 (1945), pp. 37-85, en particular, p. 37.

${ }^{28}$ Esta es precisamente la cuestión que ya abordé en: Imagenes religiosas del rey y del poder real en la Castilla del siglo XIII", "En la España Medieval", 7 (1986), pp. 709-729.

${ }^{29}$ Un análisis sistemático de síntesis de la utilización del lenguaje religioso al servicio de la propaganda política en la Edad Media en Sophie MENACHE, The Vox Dei. Communication in the Middle Ages, Nueva York-Londres, 1990.

${ }^{30}$ De este modo, se ha observado cómo la monarquía recibe la transferencia de lo sagrado del poder espiritual al poder temporal, siendo esto lo que Kantorowicz denominó Mysteries of State. Así lo ha advertido Jacques Le Goff, en las conclusiones a Paolo Cammarosano, Le forme della propaganda politica nel due e nel trecento, Roma, 1994, p. 520-521. Para la referencia al concepto de Misterios de Estado: Erns H. KanTOROwicz, Mystères de l'Etat. Un concept absolutiste et ses origines médiévales (bas Moyen Age), en "Mourir pour la Patrie et autres études", París, 1984, pp. 75-103.
} 
retornar al siglo XIII para comprender el sentido de la evolución experimentada por las distintas formas de retórica política de carácter propagandístico empleadas en tiempos más tardíos.

En el contexto de las transformaciones del siglo XIII no siempre resulta fácil establecer una frontera precisa entre lo que es elaboración de teoría política y lo que es propaganda política. No obstante, tal como ha advertido algún autor ${ }^{31}$, entre teoría política y propaganda, tanto por lo que afecta a las referencias intelectuales utilizadas, como por las condiciones de creación de las mismas, puede apreciarse una continuidad evidente, de modo que el saber que ponían en imágenes los inspiradores de la propaganda política era, con las lógicas diferencias de presentación y de tono, el mismo saber que elaboraban los teóricos.

Lo que se acaba de señalar nos lleva precisamente al problema de las implicaciones políticas del uso de lo religioso, cuando no de lo sagrado, en el marco de lo verdaderamente relevante en el marco de la historia política: el desarrollo de los conflictos políticos. Con relación a éstos, la disponibilidad de referencias religiosas o sagradas es el resultado de la capacidad que éstas por sí mismas seguían teniendo en el siglo XIII, tal como siguió ocurriendo en los siglos inmediatos, para legitimar reivindicaciones políticas. Consecuencia de ello será el apreciable uso de la manipulación en la utilización progandística de tales referencias como consecuencia de la premura impuesta por el propio desarrollo del conflicto, contribuyéndose así a difuminar el sentido original de la imagen religiosa o a desvirtuar, de acuerdo con el discurso teológico en el que se originó, el concepto de lo sagrado - pero sin perder tal significado en la perspectiva de su utilización política-, para tomar nuevo sentido al hilo de su contacto con las confrontaciones en curso.

\section{PRINCIPIOS POLÍTICOS Y RECURSOS RETÓRICOS: \\ ALGUNOS EJEMPLOS}

Desde el punto de vista de la estructura ideológico-política de la realeza castellana, cabe apreciar diversas manifestaciones del proceso de

\footnotetext{
${ }^{31}$ Resumo aquí el punto de vista de Jacques VERGER, Théorie politique et propagande politique, en "Le forme della propaganda politica nel due e nel trecento", pp. 29-44.
} 
enriquecimiento por ella experimentado a partir de la incorporación de referencias creadas en el ámbito de lo teológico y que ahora, sobre todo en la segunda mitad del siglo XIII, son objeto de una reinterpretación tal que las convertirá en algunos de los elementos integradores más carácterísticos de la ideología política castellana bajomedieval.

La intensa actividad legislativa llevada a cabo por Alfonso X se constituye en referente central a la hora de percibir estos procesos de trasferencia desde lo teológico hacia lo político, en donde alcanzan particular interpretación como consecuencia de la incidencia romanista ${ }^{32}$. Estoy bien lejos de ser la persona más adecuada para entrar en el análisis de este proceso y de sus implicaciones que, por otra parte, ya cuenta con una dilatada bibliografía $a^{33}$, no obstante, sí convendrá expresar alguna apreciación a modo de encuadre para otros problemas, en alguna medida relacionados con esta actividad legislativa, a los que habrá de hacerse aquí alusión.

Se ha señalado cómo el derecho y la teología, mediante la mutua interacción de sus técnicas y de sus percepciones, estructuraron una noción útil, lo que podría entenderse como el epistema escolástico ${ }^{34}$, dentro del cual toman su sentido buena parte de los conceptos jurídico-políticos dominantes en las monarquías bajomedievales.

La aportación inspiradora del romanismo era particularmente coherente con los principios del espíritu laico en materia de ejercicio de la potestad legislativa, pues esa aportación inspiradora romanista apuntaba preferentemente en un doble sentido: el de la preeminencia de la prescripción real sobre el derecho consuetudinario y el de la necesidad de llevar a cabo una actividad de codificación sistemática bajo el directo control real ${ }^{35}$.

\footnotetext{
${ }^{32}$ Se ha señalado la importancia como asunto de historia intelectual, política y social de la influencia que el derecho romano ha tenido en la trasformación de las relaciones de poder que tiene lugar en Occidente entre los siglos XII al XV. La variedad de dimensiones que comporta, a pesar del importante volumen de investigación ya acumulada, creo que dista aún mucho de agotarse. Véase al respecto: Jacques KRYNEN, Droit romain et état monarchique, en "Répresentation, pouvoir et royauté à la fin du Moyen Âge", edic. de J. Blanchard. París, 1995 pp. 13 y ss.

Reflejo de ello en Jerry CRADDOCK, The Legislative Works of Alfonso el Sabio. A Critical Bibliograplyy, Londres, 1986.

${ }^{34}$ Son expresiones que tomo de Alain Boureau, Droit et théologie all XIIle siècle, "Annales.E.S.C.", 47 (1992), pp. 1.113-1.125, en especial, p. 1.116.

${ }^{35}$ Algunas precisiones de interés al respecto en Robert A. MaCDONALD, Law and Politics: Alfonso's Program of political Reform, en "The Worlds of Alfonso the Learned and James the Conqueror. Intellect and Force in the Middle Ages", edic. de R.I. Burns, Princeton, 1985, pp 150-202.
} 
Como una expresión constatable de ese espíritu laico podría advertirse la propensión a monopolizar la creación del derecho, lo que, en definitiva, vendría a suponer la manifestación de una fuerte inclinación monista ${ }^{36}$. Si aceptamos, como parece evidente que así fue, estos principios como inspiradores básicos de la labor legistlativa alfonsina, estamos entonces ante la presencia de una plasmación particularmente clara de lo que Lagarde consideraba como la piedra angular del espíritu laico, en cuanto que mecanismo de transformación de las relaciones políticas en el siglo XIII: la unidad de dominación de los actos.

El desarrollo del programa de producción legislativa alfonsina se desglosó en varias fases: 1) la reclamación para la Corona del monopolio legislativo, 2) la unificación jurídica de los diversos reinos, 3) la renovación misma del derecho ${ }^{37}$. En la realización de este programa de carácter unificador, los procesos de secularización en los que se producía la incorporación a la legislación real de experiencias y normas legales de origen eclesiástico y teológico pudo jugar un papel decisivo en la reducción de la concurrencia conflictiva entre planteamientos legales de origen y sentido contrarios. Principios teológicos y normas de derecho eclesiástico formaban parte del patrimonio común de todos los territorios interesados en el proceso de transformación legislativa. Su incoporación a las reformas legales suponía contar con un apoyo en algo en torno a lo cual existía un consenso previo referible a todo el conjunto de la cristiandad. Es así que me parece un elemento a valorar la trasposición concreta de normas y conceptos desde la teología y el derecho divino y eclesiástico al nuevo derecho regio ${ }^{38}$, con

\footnotetext{
${ }^{36}$ Benjamín González Alonso, De Briviesca a Olmedo (algunas precisiones sobre el ejercicio de la potestad legislativa en la Castilla bajomedieval). en "El Dret Comú i Catalunya". edic. de A. Iglesia Ferreirós, Barcelona, 1995, pp. 43-74, en especial, pp. 43-48.

${ }^{37}$ Aquilino Iglesia Ferreirós, Fuero Real y Espéculo, "Anuario de Historia del Derecho Español", LXII (1982), pp. 115-131.

${ }^{38}$ Sobre este proceso de trasposición, sobre todo desde la teología al derecho alfonsino, reflejado en Las Siete Partidas, ya apuntó algunos ejemplos significativos el Prof. Angel Ferrari, cuyo análisis pormernorizado bien valdría un estudio específico en cada caso. Así, por ejemplo, entre estas trasposiciones destacó el concepto de creencia asignada a la ley de la misma manera que al dogma (Part. I, tít. I. ley 5, recojo aquí las referencias tal como las indica el autor aludido); la misión transcendente de los poderes temporal y espiritual, en donde está presente la idea de una predestinación del género humano (Part. I, tít. XX, introd. y Part. IV, tít. II, introd.); la idea de piedad que se traspone de ser un atributo de la divinidad creadora a la obra política de la creación (Part. I, tít. IX, introd.; Part. II, tít. XII, ley 7 y Part. II, tít. II, ley 2), las semejanzas que se establecen entre la investidura caballeresca y la ordenación sacerdotal (Part. 2, tít. 21) y. así, otros muchos temas reflejados en Las Particlas y susceptibles de este tipo de análisis. Vid.: Angel FERRARI NúNEEz. La secularización, pp. 450-452.
} 
todas sus potencialidades autorirarias para el modelo de realeza que se proyectaba. A ello hay que unir la función ejercida por esta transposición como mecanismo de reducción del conflicto que, inexorablemente, la propia reforma legislativa suponía por sus implicaciones de confrontación en cuanto a las relaciones de poder en juego como consecuencia de la evidente absorción de atribuciones que con ella se impulsaba en favor del poder real.

Ya en el plano de la retórica política es suficientemente conocida la presencia de toda una serie de conceptualizaciones que, a partir de la obra alfonsina, se convertirán en básicas en la representación del poder regio, que toman su sentido político original en este proceso de trasposición idelógica entre modelos teológicos y soluciones jurídico-políticas. Sin ánimo totalizador, algunos ejemplos bastarán para obtener una percepción suficiente de tal asunto.

La función del rey-juez se convierte en una trasposición de la idea de Dios-juez, concibiéndose la justicia real como la plasmación del premio o castigo divinos con respecto a los hombres ${ }^{39}$. Concepto político capital habría de ser el de naturaleza como vínculo político básico, del que se generaba derechos y deberes, de modo que el origen natural del poder civil libraba al estado de cualquier dependencia de los poderes espirituales y contribuía a la secularización de la sociedad ${ }^{40}$. La importancia que este concepto político había de tener en el futuro para las relaciones MonarquíaIglesia es verdaderamente decisiva y no se van a poder percibir todos los efectos en este nivel hasta que ya en el siglo $\mathrm{XV}$, aunque el asunto bien puede seguirse desde antes ${ }^{41}$, la redefinición de las relaciones entre las distintas monarquías y el Pontificado se impulse decididamente tras la liquidación del Cisma. Será entonces cuando los monarcas castellanos, empezando por Juan II y llegando sin interrupción hasta los Reyes Católicos, traten de llevar a sus máximas consecuencias la aplicación del concepto de

\footnotetext{
${ }^{39}$ Siete Partidas, part. II, tít. I, ley 7 y Fuero Real, lib. I, tít. II, ley 4. Consideraciones más amplias al respecto en mi Fundamentos ideológicos del poder real, pp. 159-165. Con relación a la idea de rey-juez y de justicia, señalaba Ferrari cómo tenía lugar el proceso de "secularización política de un concepto de Teología moral como el de justicia, mediante la paradójica divinización del mismo al considerársela como medianera entre Dios y los gobernados de un país, cuando dicho concepto se hace norma y mandato ciertos, encarnado en sus reyes y gobernantes legítimos". FERRARI, Medievalismo y teología, pp. 37-38.

${ }^{40} J$ oseph F. O’Callaghan, El Rey Sabio. El reinado de Alfonso $X$ de Castilla, Sevilla, 1996, p. 40

"José Antonio MaraVall, Estado moderno y mentalidad social (siglos XV al XV), Madrid, 1972. I. p. 222
} 
naturaleza al clero de sus reinos. Se tratará en definitiva de hacer ver al Pontificado que el vínculo de naturaleza, con los deberes que llevaba aparejados, se superponía a cualquier otra forma de relación, pretendiendo así mediatizar la existente entre el papa y cada uno de los clérigos de Castilla. Al entender, además, que ese vínculo de naturaleza se daba entre cada monarca y los clérigos naturales de su reino, se pretendía excluir la presencia de clérigos extranjeros por entender que, por encima de su propia condición eclesiástica, desarrollarían su ministerio pastoral en Castilla predeterminados por su dependencia política con respecto a un príncipe distinto del castellano por la supremacía de su condición de natural con respecto a un príncipe foráneo. Estamos en presencia, pues, de un núcleo jurídico-político argumental de primer orden en torno al cual van a girar una buena parte de las negociaciones y reivindicaciones que durante más de un siglo va a plantear la realeza castellana ante el Pontificado a fin de asegurarse un máximo control sobre su pontificado y que encontrará sus frutos, primero, en el derecho de suplicación y, más tarde, en el de presentación, fórmula característica dentro de lo que se acabe conociendo como Patronato Real ${ }^{42}$.

El vínculo de naturaleza, como es bien sabido, es una de las consecuencias políticas fundamentales de la concepción corporativa, seguramente, una de las expresiones más complejas y decisivas de ese proceso de trasposición desde lo teológico a lo jurídico-político que suele enunciarse en términos de secularización de la teoría política. No es este lugar para entrar en su análisis, objeto de atención recurrente en muy diversas publicaciones, tanto con relación a Occidente ${ }^{43}$, como a Castilla ${ }^{44}$, pero acaso sí convenga recordar algunas de sus extraordinarias consecuencias en el plano de los conceptos políticos, en cuanto que éstas son efecto directo

\footnotetext{
${ }^{4}$ Sobre los decisivos pasos dados en este proceso durante el reinado de Juan II: José Manuel Nieto Soria, El pontificado de Martín V y la ampliación de la soberanía real sobre la Iglesia castellana (1417-1431), "En la España Medieval", 17 (1994), pp. 113-132.

${ }^{43}$ A.H. Chroust, The Corporate Idea and the Body Politic in the Middle Ages, "Review of Politics", 9 (1947), pp. 423-452; Erns H. KanTOROWICZ, Los dos cuerpos del rey. Un estudio de teologia politica medieval, Madrid, 1985, pp. 188-223. J.P. CanNing, The Corporation in the Political Thought of the Jurist of the Thirteenth and Fourteenth Centuries, "History of the Political History", 1 (1980), pp. 9-32.

${ }^{4 H}$ José Antonio Maravall, La idea de cuerpo mistico en España antes de Erasmo, en "Estudios de historia del pensamiento español". I, Madrid, 1973, pp. 191-214 y Del régimen feudal al régimen corporativo en el pensamiento de Alfonso X, ibid., pp. 103-156 y José M. NiETO SORIA, Fundamentos ideológicos, pp. 90-98.
} 
de esa extrapolación política de las referencias teológicas sobre las que se fundamentaba la concepción corporativa. Entre estas consecuencias, baste señalar el carácter de resultantes con respecto a dicha concepción corporativa de la primitiva idea de pro comunal ${ }^{45}$, como adelanto de lo que acabará siendo el concepto más complejo de bien común, el principio político pro patria mori $^{46}$, del que se han encontrado precedentes en la legislación alfonsina ${ }^{47}$; la definición de un modelo de obediencia de clara inspiración teológica sólo coherente en el contexto englobador de la concepción corporativa $^{48}$; el principio de laese maiestatis, en el que se establece una equiparación entre traición al rey y traición a Dios mismo $^{49}$ y desde el que se justificará el carácter sacrílego de la resistencia al rey. Me pregunto si acaso no habría que buscar también en la propia concepción corporativa y en su capacidad para justificar una amplia absorción de atribuciones para el poder real uno de los fundamentos, entre otros ${ }^{50}$, de la función de represión de la herejía como algo que le compete directamente ${ }^{51}$ y que se acaba aprovechando por la realeza como base para fundamentar la iniciativa regia

\footnotetext{
${ }^{45}$ Algún ejemplo en El Libro de los doze sabios, edic. de John K. Walsh, Madrid, 1875, cap. IX, p. 83:"sañudo deve ser el rey o prínçipe o regidor de reyno contra los malos e contra aquellos que non guardan serviçio de Dios, nin pro común de la tierra, e roban a los que poco pueden, e les toman lo suyo contra su voluntad o cometen o fazen trayçiones o maldades, o yerran contra su persona non lo temiendo, e atreviéndose a él"; en el Espéculo, lib. I, tít. I. prólogo: "Nos diexiemos de suso que feziemos leyes a pro de nuestras tierras e de nuestros regnos e mostraremos muchas razones porque conviene que las feziesemos"; en Las Partidas, part. I, prólogo: "Onde nos, por toller todos estos males que dicho avemos, fiziemos estas leyes que son scriptas en este libro, a seruicio de Dios e a pro comunal de todos los de nuestro sennorío, porque connoscan e entiendan ciertamientre el derecho, e sepan obrar por él e guardarse de fazer yerro porque no cayan en pena. E tomamoslas de los buenos fueros e de las buenas costumbres de Castiella e de León e del derecho que fallamos que es mas comunal e más prouechoso para las gentes en todo el mundo". También en Las Partidas, part. II, tít. I, ley 9: "[Los reyes] deben siempre mas guardar la pro comunal de su pueblo que la suya misma, porque el bien e la rriqueza dellos es commo suyo"

${ }^{+6}$ Erns H. Kantorowicz, Mourir pour la patrie, pp. 131-133.

${ }^{47}$ "E a la tierra han gran debdo de amarla e de acrescentarla e morir por ella, si menester fuere" (Partidas, part. IV, tít. XXIX, ley 4). Este texto ha sido considerado como un precedente relevante de la ideología del pro patria mori. debiendo integrarse en las posibilidades que abre la concepción corporativa. Véase al respecto José A. MARAVALL, Del régimen feudal al régimen corporativo, p. 143.

${ }^{+8}$ Basándome en fragmentos de los Castigos e documentos del rey don Sancho y en el Libro de los Cien Capítulos, tal como se puede ver en mi Fundamentos ideológicos, , p. 117.

${ }^{49}$ Partidas, part. VII, tít. II, ley 1.

${ }^{50}$ Piénsese en la normativa del IV Concilio de Letrán, en concreto, en su canon 3, con respecto a la exigencia de colaboración en materia de herejía para el brazo secular.

${ }^{51}$ Espéculo, 1,2,3.
} 
para denunciar como herética la actitud de los que traicionan la lealtad debida al rey ${ }^{52}$.

Si en todo lo que se acaba de señalar es posible encontrar indicios de ese proceso de secularización, no entendido como liquidación de los fundamentos religiosos del poder real, sino como sujetos a todo un proceso de reinterpretación y de integración en el ordenamiento jurídico y político que da nuevo sentido a éste, habrá que llamar también la atención respecto de otro rasgo particularmente potenciador de tal proceso. Este es el de la propia lengua en que se plasman estos proyectos y estas conceptualizaciones: el castellano. Seguramente habría que conceder algún significado a la utilización sistemática en la documentación oficial del castellano en lugar del latín a la hora de producir un efecto añadido de secularización política. Con ello se favorecía la liquidación del monopolio clerical sobre los textos oficiales. Es desde la propia realeza desde donde más se potencia esta sustitución lingüística ${ }^{53}$. Naturalmente, no es casualidad que sean aquellas actividades políticas aún dependientes del uso del latín, como las relaciones diplomáticas, donde el protagonismo clerical no aparezca amenazado. En cualquier caso, estamos ante un factor que, más que incidir en que se produzcan cambios a corto plazo, se limita a ofrecer unas potenciales expectativas, pues no olvidemos que la cultura de élite sigue siendo monopolio clerical y predominantemente latina.

\footnotetext{
${ }^{52}$ Desde esta perspectiva pueden interpretarse algunos de los episodios de la guerra civil entre el infante don Sancho y Alfonso $X$. quien consideró la sublevación de su hijo como un acto de falta de temor a Dios obteniendo el apoyo pontificio para la excomunión de su hijo y los prelados que lo apoyaban. Véase mi Sancho IV, 1284.1295, "Corona de España (Reyes de Castilla y León)". III, Palencia. 1994, pp. 47, 50-51.

${ }^{5}$ Una valoración política de la potenciación del castellano durante el reinado de Alfonso $\mathrm{X}$ en: Georges MARTIN. Alphonse X et le pouv'oir historiographique. "L histoire et les nouveaux publics dans l'Europe médiévale (XIIIe-XVe siècles), edic. de J.-Ph. Genet. París, 1997, pp. 229-245. en particular. pp. 238-239. Así señala este autor cómo la utilización sistemática del castellano observada con Alfonso X, aplicada tanto a la documentación real como a las distitnas empresas científicas, literarias. historiográficas, como jurídicas tiene significaciones políticas incuestionables. Así. deben considerarse las consecuencias que pudo tener la elección del castellano a la hora de promover una jerarquización geopolítica del reino, no dudándose en calificar el castellano como la lengua de España, pudiendo valorarse tal hecho como una estrategia de ordenación política del reino y de su espacio.
} 


\section{EL REY COMO IDEAL ÉTICO-MORAL}

La valoración ético-moral del monarca constituye un rasgo muy carácterístico de la función real durante toda la Baja Edad Media ${ }^{54}$. Se ha señalado por algún autor cómo a partir de Alfonso X se inaugura una época filosófico-moral ${ }^{55}$, cuyo vigor se incrementará con Sancho IV, reflejándose no sólo en los tradicionales espéculos de príncipes y en las diversas formas de literatura didáctica y sapiencial ${ }^{56}$, sino también, en los propios textos legales ${ }^{57}$.

Sin embargo, este modelo ético-filosófico, sobre todo cuando se plasma en textos literarios, queda definido, como rasgo característico en la Castilla del siglo XIII, a partir de una considerable variedad de influencias. Junto a las ya tradicionales bíblicas y patrísticas, hay que llamar la atención sobre la irrupción de los autores mendicantes, sobre todo reflejados en lo que se ha dado en llamar, con relación a esta cuestión, como la corriente franciscanista, con importante continuidad en el siglo XIV, sin que tampoco falte la aportación dominica ${ }^{58}$. La corte real castellana tuvo, además, una importante capacidad de incorporación de influencias extranjeras en esta materia, lo que queda plasmado de modo relevante por la llegada a la corte alfonsina de los espéculos de príncipes englobados en el denominado grupo de San Luis ${ }^{59}$, así como en la recepción de las diversas expresiones de las

\footnotetext{
${ }^{54}$ Sobre esa valoración predominantemente ético-moral del monarca bajomedieval, algunas puntualizaciones de valor general en Jacques KRYNEN, Idéal de prince et pouvoir roval en France à la fin du Moyen Age (1380-1440). Etude de la littérature politique du temps, Paris, 1981 y. del mismo autor. L'Empire du roi. Idées et crovances politiques en France, XIIIe-XVe siècle, París, 1993.

${ }^{55}$ Juan Beneyto, Los origenes de la ciencia política en España, Madrid, 1976, p. 249.

${ }^{56}$ Algunas perspectivas de valoración política de textos englobables dentro de esta literatura sapiencial y didáctica en: Hugo O. BIZZARRI, Las colecciones sapienciales castellanas en el proceso de reafirmación del poder monárquico (siglos XIII $y$ XIV), "Cahiers de Linguistique Hispanique Médiévales". 20 (1995), pp. 35-73; Bonifacio Palacios Martín. El mundo de las ideas politicas en los tratados doctrinales españoles: los 'espejos de príncipes'(1250-1350), en "Europa los umbrales de la crisis (1250-1350). XXI Semana de Estudios Medievales de Estella", Pamplona, 1995, pp. 463-483 y Marta HARO CORTÉS, La imagen del poder real a través de la composición de castigos castellanos del siglo XIII, Londres, 1996.

${ }^{57}$ De lo que da buen ejemplo el título V de la segunda Partida.

${ }^{58}$ Palacios Martín, El mundo de las ideas políticas, pp. 480-481.

${ }^{59}$ Sobre la influencia de los espéculos del grupo de San Luis, con la obra de Vicente de Beauvais a la cabeza, y su difusión en España: Palacios Martín, El mumdo de las ideas políticas. pp. $471-473$.
} 
corrientes arsitotélico-tomistas que afectaron de lleno al problema del ideal moral regio ${ }^{60}$. Rasgo particular del caso castellano habría de ser la influencia de la tradición arábigo-oriental, muy presente en los espéculos castellanos del XIII ${ }^{61}$. Por todo ello, podría pensarse que, sobre todo en el caso de los espéculos, la diversificación de fuentes sobre las que se fundamentan debió producir un inevitable efecto de relativización de los criterios de origen eclesiástico-religioso sobre los que se construía el ideal moral de monarca. No obstante, tal apreciación es matizable si se tiene en cuenta que, dado el predominio de los autores eclesiásticos en tal tipo de obras, se consiguió desarrollar por éstos un cierto proceso de pacífica síntesis entre lo propio de la doctrina cristiana en materia de virtudes regias y lo proveniente de otros orígenes, no faltando incluso la decidida absorción de esto último por lo primero. Es por ello que tengo la impresión de que acaso pudo producir un efecto de mayor aperturismo hacia nuevos criterios virtuosos la destacada presencia mendicante entre los autores de este tipo de obras doctrinales y el interés de franciscanos y dominicos, piénsese, por ejemplo, en el caso destacado de un fray Juan Gil de Zamora ${ }^{62}$, por los problemas didácticos, mostrándose atentos a lo que eran las nuevas inquietudes morales y sociales. Es posible que esta circunsancia pudiera tener un efecto más decisivo que el que pudiera deducirse de los nuevos aportes intelectuales, ajenos a la tradición cristiana, que siempre podían ser objeto de reinterpretación a partir de los criterios de ésta.

Muchas de las circunstancias apuntadas podrían acaso detectarse en algunos de los rasgos de una de las obras más características de la literatura didáctica dirigida a la formación del rey como fue Castigos e documentos del rey don Sancho ${ }^{63}$. En este texto bien podrían encontrarse sintetizadas algunas de las contradicciones resultantes de lo que puede ser la coexistencia

\footnotetext{
${ }^{60} \mathrm{La}$ influencia del aristotelismo tomista queda comprobada por la importante difusión de manuscritos latinos y traduciones del De Regno y el De Regimine Principum de Santo Tomás de Aquino que se produjo en España. Ibid., p. 474.

${ }^{\circ}$ HaRO CORTÉS, La imagen del poder real, p. 12

${ }^{6}$ Sobre sus aportaciones al pensamiento político de la época: Manuel CASTRO CASTRO, Las ideas politicas y la formación del príncipe en el 'De Preconiis Hispaniae' de Fray Juan Gil de Zamora, "Hispania" 88 (1962). pp. 507-541.

${ }^{63}$ Sobre textos manuscritos, ediciones y estudios relativos a los Castigos e documentos del rey don Sancho, además del trabajo ya citado de Marta Haro Cortés, puede verse un repertorio bibliográfico de la misma autora en C. ALVAR y J.M. LuCía MEGías, La literatura en la época de Sancho IV. Alcalá de Henares, 1996, pp. 558-560.
} 
entre un espíritu laico, que todavía se halla en una fase incipiente de desarrollo y que, en el marco de este tipo de literatura, recibe nuevos apoyos a partir de esa múltiple influencia antes $\operatorname{apuntada}^{64}$, y la presencia de criterios clericales que abordan el problema de la virtud y, en general, de los ideales de vida, desde el predominio de las exigencias de la doctrina cristiana $^{65}$

Se ha apuntado, con relación a los Castigos, la tendencia a la acentuación del matiz cristiano del rey ${ }^{66}$. Del mismo modo, al valorar la utilización de los recursos retóricos presentes en esta obra, se ha llamado la atención sobre sus evidentes concomitancias con la práctica de la predicación $^{67}$, apuntando tal consideración al posible protagonismo de la influencia dominica en diversas partes de su redacción ${ }^{68}$. Aceptando todas estas valoraciones, dada la evidencia de las mismas, todo ello se hace, en cambio, compatible con la apreciación de la distancia recorrida entre los planteamientos bajo los que se abordaba el problema de las virtudes en un texto como El Setenario ${ }^{69}$, con una atención prácticamente exclusiva a las virtudes tradicionales contempladas en la doctrina cristiana ${ }^{70}$ y otro texto, como Castigos, en donde ese mismo enfoque es compatible con la consideración de las opiniones sobre el tema de la virtud de los gobernantes de autores como Aristóteles, Macrobio, Plotino o Hermógenes, entre otros, dando

\footnotetext{
${ }^{64}$ Múltiple influencia a la que, además, en el caso de los Castigos, se vendría a añadir la proveniente del derecho secular y del derecho canónico, tal como ha señalado Hugo $\mathrm{O}$ BIZZARRI, Las colecciones sapienciales castellanas, p. 56.

${ }^{65}$ Así se ha señalado, con relación a los Castigos, cómo "los capítulos 17 al 28, imprimen un giro, una regresión hacia la doctrina religiosa, a partir de la presencia amenazante de fuerzas externas (a veces interiorizadas). Aunque de nuevo se interrumpe temporalmente el hilo argumentativo para entrar a lo largo de los tres capítulos siguientes en el exhorto al ejercicio de tres virtudes (piedad, paciencia, misericordia: caps. 29, 30 y 31), que podemos agrupar como virtudes del humilde. Son los tres pilares sobre los que se asienta la ley de los cristianos y la vida de Jesucristo y de Santa María, su madre". Rafael BELTRÁN, El valor del consejo en los Castigos e documentos del rey don Sancho, en La literatura en la época de Sancho IV, p. 114.

${ }^{66}$ Hugo O. BIZZARRI, Las colecciones sapienciales castellanas, p. 53.

${ }^{67}$ Sobre la presencia de la retórica de la predicación en los Castigos, Charo MORENO, La inserción de los exempla en Castigos e documentos de Sancho IV. La retórica del sermón en una empresa de Estado, en "La literatura en la época de Sancho IV", pp. 469-477.

${ }^{68} \mathrm{Ibid}$., p. 469.

${ }^{69}$ Sobre el significado político de esta obra en el contexto de la obra alfonsina: Georges Martin, Alphonse X ou la science politique. Septénaire, 1-11, "Cahiers de Linguistique Hispanique Médiévale", 18-19 (1993-94), pp. 69-100.

${ }^{70}$ Setenario, edic. de K.H. Vanderford, Barcelona, 1984, ley V, pp. 11-12.
} 
particular reconocimiento modélico a los consejos de Aristóteles a su discípulo Alejandro Magno ${ }^{71}$.

A partir de las consideraciones precedentes podrían apuntarse algunas hipótesis con respecto al problema de la consideración de la caracterización ético-moral del modelo regio:

1) Los eclesiásticos (frecuentemente franciscanos y dominicos) siguen jugando un papel muy apreciable en la definición de las virtudes reales, pero quedando su propuesta contrastada con otras referencias de origen muy diverso ajenas, al menos parcialmente, a la doctrina cristiana, lo que, a pesar del dominio clerical, abre expectativas de transformación de los modelos virtuosos tradicionales.

2) Si los eclesiásticos, por tanto, no han perdido capacidad para delimitar el modelo virtuoso de monarca, sí han perdido definitivamente capacidad de control sobre el cumplimiento de ese ideal. Por de pronto, los textos que se aceptan en la corte lo son a resultas de la demanda regia, cuyo criterio es el que acaba otorgando la "oficialidad" de los mismos. Pero, además, el propio control cultural regio impone los criterios de evaluación de la adecuación efectiva de las acciones regias al modelo virtuóso propuesto. De este modo, la posesión de virtud se valora en clave política. Así, por ejemplo, la lucha contra el infiel y el esfuerzo real en la misma se interpreta como evidencia del amor a Dios, o se hace exhibición de sabiduría por escuchar a los consejeros, o de justicia por perdonar tal traición o, por el contrario, si conviene, por castigarla de la manera más ejemplar.

3) En este desplazamiento de los eclesiásticos en el control del ejercicio práctico de las virtudes reales, más que en cuál sea el enunciado concreto de las mismas, prodría advertirse otro factor particularmente valorable en las trasformaciones secularizadoras que pudieran haber afectado al poder real.

En cualquier caso, no se podrá limitar a estas apreciaciones el asunto de la consdieración del rey como ideal virtuoso, puesto que ésta es una cuestión que presenta múltiples conexiones con el problema del origen divino de la realeza y la función del rey como vicario de Dios, por lo que habrá de retomarse la cuestión desde esta perspectiva en el siguiente apartado.

\footnotetext{
${ }^{71}$ Castigos e documentos del rey don Sancho, Biblioteca Autores Españoles, LI, Madrid, 1952, cap. LVIII, pp. 185-186.
} 


\section{EL ORIGEN DIVINO DE LA REALEZA}

La segunda mitad del siglo XIII representó en Catilla una época de reafirmación del origen divino de la realeza, teniendo lugar una explicitación bastante intensa de tal rasgo de la ideología política ${ }^{72}$, acentuándose durante el reinado de Sancho IV la caracterización teocéntrica de la monarquía ${ }^{73}$. La fórmula "rey por la gracia Dios", o "rex gratia Dei", contaba en la Castilla del siglo XIII con una larga tradición que se ha remontado por el prof. Ubieto a la época de Fernando I, quien rompería así con una ideología del poder regio basada esencialmente en la capacidad de dirección militar que habría caracterizado a los monarcas inmediatamente precedentes. Desde este punto de vista, es posible que tuviera algún significado para los reyes castellanos del siglo XIII que el primer monarca que había ostentado la condición de rey de Castilla tuviera ya el atributo de rey por la gracia de Dios $^{74}$. como si se tratase de un rasgo básico que se hallaba en el origen de la realeza castellana. De este modo, la fórmula "rey por la gracia de Dios", como símbolo expresivo más caracterísco del origen divino de la realeza castellana, se mantuvo con toda pujanza como rasgo de los monarcas

\footnotetext{
72Manifestaciones de esta reafirmación y explicitación del origen divino del poder real en Castilla en José A. Maravall. Del régimen feudal al régimen corporativo. pp. $116-117$ y José M. Nieto Soria, Fundamentos ideológicos. pp. 51-60.

73: Al leer la obra con atención se hace evidente el alto grado de teocentrismo que abarcan tanto tanto las teorizaciones como los propios ejemplos que se aducen para ratificar y apoyar los principios doctrinales. De hecho, el gran castigo politico, la enseñanza esencial que se desprende de los Castigos de Sancho IV es la sacralización de la monarquía. Esto se consigue partiendo del presupuesto del origen divino del rey y mediante una asociación de conceptos, que se repite constantemente a lo largo de la obra: "Pues el rey que tiene logar de Dios e es a su semejança (..) Se ensalza y especifica rotundamente el lazo divino de la monarquía porque a partir de esta coordenada ideológica se justificicara la superioridad absoluta del rey no sólo política, sino también moral". HARO CORTÉs, La imagen del poder real. pp. 50-51.

${ }^{74}$ Así lo ha observado Antonio UBIETO ARTETA, El origen divino de la realea en "Los origenes de los reinos de Castilla y Aragon". Zaragoza. 1991. pp. 179-180.
} 
castellanos en el siglo XIII ${ }^{75}$, completándose con la doctrina del vicariato regio, ampliamente desarrollada en la obra legal alfonsina ${ }^{76}$.

Pero también con relación a las fuentes historiográficas se ha hecho recientemente particular incidencia sobre el refejo en ellas de la dimensión divina de la realeza castellana, dando base a unos contenidos ideológicos típicamente providencialistas. Las acciones de los monarcas no eran casuales, ni respondían a condiciones simplemente circunstanciales, sino a la directa influencia divina ${ }^{77}$, cuya intervención encaminaba el desarrollo de los acontecimientos en el sentido que más convenía a los intereses de la dignidad real. De igual modo, se ha señalado cómo uno de los elementos básicos desde los que se concibe la elaboración de las estorias de Alfonso X es "destacar el origen divino del 'imperium' heredado por los miembros de la 'linna'" que desemboca inexorablemente en el monarca reinante ${ }^{78}$.

\footnotetext{
${ }^{75}$ Así queda claramente de manifiesto en los formulismos documentales de las cancillerías reales, en los que, dependiendo del tipo documental, la expresión "rex gratia Dei" o "por la gracia de Dios rey de..." se podía completar, de forma variable para cada reinado, con otros símbolos y formulismos documentales, tales como crismones, invocaciones mogramáticas o invocaciones explícitas diversas, que acentuaban esa idea de relación entre el rey y la divinidad. Así puede verse, para Fernando III, Julio GONZÁLEZ, Reinado y diplomas de Fernando III, I, Córdoba, 1980, pp. 512-528. Para Alfonso X: Antonio J. LÓPEZ GUTIÉRREZ, La cancillería de Alfonso $X$ a través de las fuentes legales y la realidad documental. Oviedo, 1990 (microforma) y María Josefa SANZ Fuentes, Instituciones de Andalucía. Estudio diplomático, en "Diplomatario andaluz de Alfonso X", coord. por M. González Jiménez, Sevilla, 1991, pp. CLXXV-CCI. Para Sancho IV: Luis SÁnChez BELDA, La cancillería castellana durante el reinado de Sancho IV, "Anuario de Historia del Derecho Español", XXI (1951), pp. 171-223. También para Sancho IV, y ya hasta Alfonso XI: María Isabel OsTOLAZA ELIzONDO, Administración y documentación pública castellano-leonesa durante el reinado de Sancho IVAlfonso XI (1282-1350). Organismos, atribuciones, tipología documental, Madrid, 1991.

${ }^{76} \mathrm{Tal}$ como queda recogido, sobre todo en Partidas, II, I, 5.

${ }^{77}$ Así lo señala Maurizio Tuliani, quien añade que "el milagro y la profecía son también elementos fundamentales del reconocimiento del carácter divino del poder real que contribuyen a reforzar el fenómeno legendario en torno a la figura del rey. La leyenda constituye una parte del sistema de propaganda destinado a alimentar la devoción". Maurizio TULIANI, La idea de reconquista en un manuscrito de la 'Crónica General' de Alfonso X el Sabio, "Studia Historica. Historia Medieval", 12 (1994), pp. 3-23, en particular, p. 7. Tal rasgo de la historiografía alfonsina se debe entender como relacionado directamente con el hecho de que, tal como ha observado Georges Martin, la actividad historiográfica en la corte alfonsina queda vinculada al impulso del propio proyecto político regio, siendo consciente la monarquía de la utilidad de los textos de historia en el proceso de legitimación de tal proyecto. Georges MarTIN, Alphonse X et le pouvoir historiographique (cit. supra). Véase también: Inés FERNÁNDEZ ORDÓÑEZ, Las 'Estorias' de Alfonso el Sabio, Madrid, 1992.

${ }^{78}$ Inés FERnÁNDEZ-Ordóñez, Las 'Estorias' de Alfonso el Sabio, Madrid, 1992, p. 33-34. Esta misma autora señala cómo: "Alfonso justifica el origen divino de un sistema político en el que el personaje que posee el 'imperium', sea el rey u otra dignidad, ocupa el puesto central y obtiene el derecho al 'señorio' por descendencia directa desde el primer hombre, creación de Dios" (ibid., p. 34).
} 
Aceptada la condición de rey y de realeza de origen divino, la monarquía trató de sacar todas las consecuencias posibles de tal circunstancia en favor de sus pretensiones políticas. El rey adquiría el carácter de especial protegido de la divinidad, lo que incluía, no sólo a su persona ${ }^{79}$, sino también, como refleja el Fuero Real, sus derechos políticos y jurídicos ${ }^{80}$. La vinculación entre el rey y la justicia era el resultado de la condición regia de vicario de Dios ${ }^{81}$.

¿Pudo llegarse al extremo de entender que entre los privilegios que recibía el rey como consecuencia de su vinculación con la divinidad estaba incluso el de hacer milagros? Convendría, en primer lugar, situar en el contexto mental de la época el concepto de milagro que quedaba perfilado con toda precisión en la Primera Partida ${ }^{82}$. En ella, al definir "quántas cosas a mester el miraglo para seer verdadero", se apuntan cuatro rasgos: que el milagro se produzca por poder de Dios, que se manifieste por producir algo contra natura, que sea consecuencia de merecimiento de santidad y de bondad "que aya en sí aquél que lo faze o aquellos pora quien es fecho" y, finalmente, que sirva para confirmamiento de la fé. De entre estos rasgos, convendrá destacar que el milagro se concebía, por tanto, como algo que se originaba en Dios mismo, como una donación que éste hacía en favor de quien utilizaba como su instrumento para su ejecución o en favor de su beneficiario y que se interpetaba como un indicio de la santidad o bondad de quien lo ejecutaba o de quien se favorecía de su realización.

Con estas premisas, no parece probable que desde la monarquía se pudiera amparar una creencia que supusiera que alguien poseyera de por sí la cualidad milagrera de forma sistemática, tal como se pretendía, por ejemplo, para los reyes de Francia. Del mismo modo, la referencia a milagros relacionados con la intervención real, en el contexto de la mentalidad alfonsina reflejada en el texto de Las Partidas, podría tener una

\footnotetext{
79" Nunca fue omne que punase en buscar mal al rey que le non diese Dios quebranto ante que muriese". Libro de los Çien capítulos, edic. de A. Rey, Bloomington, 1960, cap. III, p. 5

${ }^{80}$ Fuero Real, I, V, 4.

81 "E los sanctos dixeron que el Rey es sennor puesto en la tierra en lugar de Dios para conplir la justiçia e dar a cada uno su derecho, e por ende lo llamaron coraçon e alma del pueblo; ca asy commo el alma yaze en el coraçon del omne, e por ella bive el cuerpo e se mantiene, asy en el Rey yaze la justiçia, que es vida e mantenimiento del pueblo de su sennorio". Partidas, II, I, 5

${ }^{82}$ Partidas, I, IV, 66.
} 
finalidad propagandística evidente: demostrar la bondad, cuando no la santidad, de quien era objeto del milagro o de quien actuaba como su mediador.

El problema del milagro como relacionado con la intervención regia ha sido particularmente abordable a partir de una obra bien rica en referencias de esta índole como es el caso de las Cantigas de Santa María. Se ha aludido por distintos autores a la cantiga ${ }^{83}$ en la que Alfonso $\mathrm{X}$ rechaza tener las cualidades sanadoras de los reyes de Francia, al negarse a la imposición de manos como medio de curación a una niña cordobesa ${ }^{84}$. Ya he señalado en otras ocasiones cómo, desde el punto de vista políticoreligioso, me parece que el significado de esta cantiga apunta, más que hacia la negación de que pueda existir alguna relación entre rey castellano y acción milagrosa, a la valoración por éste como superchería, neicedade, se dice en el texto, de cualquier creencia en la virtud milagrera innata al ministerio regio en el caso de cualquier monarca, castellano o no, remitiendo tal facultad a un plano celestial, Dios mismo o la Virgen, en este caso, lo que sería acorde con el planteamiento general presente en Las Cantigas. A la vez podría también considerarse dicha cantiga como indicio de que, a pesar de todo, existía en Castilla alguna forma de creencia popular en la capacidad del rey para obrar milagros, lo que, independientemente de la ausencia de rito sistemático alguno que así lo justificase, tampoco sería tan extraño, insisto, como creencia popular, en el contexto mental de la época ${ }^{85}$. Por otra parte, la actitud real de la remisión del origen del milagro a una referencia celestial, sería coherente con ese concepto de milagro reflejado en el texto de la Primera Partida antes aludido.

Sin embargo, sin apartarnos de esta misma obra, se puede ver cómo Alfonso $\mathrm{X}$ no deja pasar la oportunidad de proclamar alguna forma de vinculación del rey castellano con la acción milagrosa. Tras afirmar en la cantiga 122 que "miragres muitos pelos reis faz Santa Maria cada que lle praz", se describen, en diversas cantigas hasta nueve intervenciones milagrosas de la Virgen referentes al rey o algún miembro de la familia real,

\footnotetext{
${ }^{83}$ La cantiga n" 321

${ }^{84}$ Alusiones al respecto en mi Fundamentos ideológicos del poder real. pp. 68, en donde se puede encontrar referencia a distintas opiniones sobre el problema de la taumaturgia regia y más recientemente, Joseph F. O’Callaghan, El Rey' Sabio, pp. 48-49.

${ }^{85}$ José M. Nieto SORIA, La monarquía bajomedieal castellana ¿Una realeza sagrada?, "Homenaje al Prof. Juan Torres Fontes", II, Murcia, 1987. pp. 1.225-1.237.
} 
la propia cantiga 122 , así como la $235^{86}, 256^{87}, 280^{88}, 292^{89}, 295^{90}$, $345^{91}, 348^{92}$ y $377^{93}$, destacándose la especial protección divina o los merecimientos del beneficiario para que ésta se produzca.

A mi modo de ver, tales expresiones de actos milagrosos relacionados con el monarca deben entenderse como manifestación del concepto de monarquía de origen divino del que resulta que el milagro real es posible, no como consecuencia de una capacidad innata a la condición real, sino como consecuencia de la relación privilegiada que mantiene con la divinidad, origen del milagro, siendo así una expresión más del eje de vinculación Dios-rey. No se trata de que el rey se atribuya una capacidad de hacer milagros, sino que, por su función real, a la que pueden unirse sus cualidades personales de cristiano ejemplar, puede confiar en que, como consecuencia de su condición de vicario de Dios, situado al frente de una monarquía de origen divino, la protección divina se pueda traducir en un hecho sobrenatural, en milagro. Naturalmente, todo ello, sin olvidar que la plasmación literaria o historiográfica de tales acontecimientos maravillosos, cuya narración se elabora en el calor de la corte real, lo que, en último término, persiguen es un efecto propagandístico de la realeza, al convertirse en sujeto de la especial protección divina, y del rey, como merecedor por sus cualidades de bondad o santidad - según el referido texto de Las Partidas- de tal protección. De este modo, la relación entre rey y milagro

\footnotetext{
${ }^{86}$ "Esta é como Santa Maria deu saude al rey don Affonso quando foi en Valadolide enfermo que foi juygado por morto".

${ }^{87}$ "Como Santa Maria guareceu a reya dona Beatriz de grand'enfermidade, porque aorou a sa omage con grand'esperança".

${ }^{88}$ "Como el rei pidiu mercee a Santa Maria que o guarecesse dua grand enfermidade que avia; e ela, como sennor poderosa, guarecé-o".

${ }^{89}$ "Como el rey don Fernando veo en vision ao tesoureiro de Sevilla e a maestre Jorge que tirassen o anel do seu dedo e o metessen no dedo da omagen de Santa Maria".

90 "Como Santa Maria apareçeu en vision a un rey que a servia en todas aquelas cousas que el sabia e podia, e semellava-lle que se omildava contra el en gualardon do serviço que lle fezera".

91 "Como Santa Maria mostrou en vison a uu rei e a hua reya como aia gran pesar porque entraron mouros a sa capela de Xerez".

92" Como Santa Maria demostrou a uu rey que trobava por ela gran tesouro d'ouro e de prata".

93" Como un rey deu ua escrivania dua vila a un seu criado, e avia muitos contrarios que o estovavan contra el rey, e prometeo algo a Santa Maria do Porto, e fez-Il' aver".
} 
se integraba en la panoplia de los instrumentos al servicio de la propaganda regia.

El que en el pensamiento político castellano del siglo XIII se atribuyera a la monarquía un origen divino y al rey un carácter de vicario de Cristo y el reino se convirtiese, en consecuencia, en un señorío divinal era algo que, en sí mismo, no ofrecía especial interés desde el punto de vista de caracterización particular del pensamiento de ese momento con relación a tiempos anteriores, por tratarse de criterios que ya contaban con una larga tradición plurisecular previa, tanto en el mundo hispánico como en el occidental ${ }^{94}$. Lo que, sin embargo, permite valorar en toda su importancia la presencia de tales creencias es que ahora, sobre todo en la segunda mitad del siglo XIII, se saquen consecuencias políticas precisas que permiten dar sólido fundamento ideológico a un modelo autoritario de monarquía, estableciendo un horizonte de pretensiones para el poder real incluso susceptible de ampliación en el futuro, cuando a ese soporte ideológico se puedan añadir los últimos avances del pensamiento jurídico favorables a ese tipo de opciones potenciadoras de una opción monárquica decididamente autoritaria que trata de postergar fórmulas limitadoras que le resulten incovenientes. El mecanismo intelectual básico por el que se producirá ese efecto de conversión de lo que eran principios ideológicos esenciales del poder monárquico (origen divino, vicariato, señorío divinal) en elementos típicos de la caracterización concreta de un modelo monárquico de preensiones autoritarias consistirá, si así se quiere llamar, en un proceso de secularización por el que se da traducción política precisa a tales principios ideológicos para obtener como resultado las implicaciones más favorables para la definición del poder regio que aquéllos permiten y para lo que se contaba con el utilísmo referente de lo que había sido la expansión ideológico-política del poder pontificio ${ }^{95}$. Con ello se daba contenido

\footnotetext{
${ }^{94}$ Véase para época altomedieval con relación a tal asunto: Manuel García PELAYO, El reino de Dios como arquetipo político. Estudio sobre las fases políticas de la Alta Edad Media, Madrid, 1959.

${ }^{95}$ Sobre los fundamentos ideológicos del poder pontificio y su aplicabilidad para la comprensión de la evolución hacia opciones autoritarias de los poderes monárquicos: Walter Ullmann, Medieval Papalism. The Political Theories of the Medieval canonist, Londres, 1949; Brian TIERNEY, Church Law and Constitutional Thought in the Middle Ages, Londres, 1979 y, del mismo autor, Religion and the Growth of constitutional Thought, 1150-1650, Cambridge, 1982. Con relación al proceso de matización y de redefinición ideológica del poder pontifició observado específicamente en el siglo XIII a partir de las obras de los canonistas más relevantes de la época puede verse: John A. WATT, The Theory of Papal Monarchy in the Thirteenth
} 
concreto a una fórmula que bien podría calificarse como autoritarismo teocrático, hacia el que se proyectaban como horizonte político deseable las pretensiones del poder regio.

La vigorosa persistencia en la Castilla del siglo XIII de fórmulas alusivas al origen divino de la realeza fue claramente valorada por Alfonso $\mathrm{X}$ como una afirmación de que, al provenir su autoridad directamente de Dios, sin mediación alguna de papa o emperador, quedaba confirmada su plena autonomía como poder político incontestable dentro de su reino ${ }^{96}$. Juan Gil de Zamora, como preceptor elegido por Alfonso X para ocuparse de la formación del príncipe don Sancho, aleccionó bien sobre estos principios a su pupilo en el De Preconiis Hispaniae, llegando a situar al rey, como vicario de Dios, en una especie, según M. Castro, de orden sobrenatural propio de un semidios ${ }^{97}$. Parece evidente que Sancho IV se aprendió bien esta lección, sacando consecuencias de cara a propiciar, desde criterios típicamente providencialistas, la interpretación más autoritaria del poder real, al fundamentar sus derechos al trono -en el contexto de la ruptura con el Rey Sabio- en una decisión divina que estaba por encima de la voluntad de su padre y de cualquier derecho sucesorio ${ }^{98}$. Bien es verdad que Fray Juan Gil de Zamora también recordó a su discípulo cómo debía tener presente la dependencia del rey con respecto a su pueblo: "vos estis propter populum et per populum, non autem populus propter vos vel per vos"99. Parece

Century. The Contribution of the Canonists, Nueva York, 1965. Sobre el proceso de trasposición de las experiencias ideológicas y político-administrativas desde el Papado a las monarquías: Jacques VERGER, Le transfert de modèles d'organisation de l'Église à l'État à la fin du Moyen Age, en "État et Église dans la genèse de l'État Moderne", pp. 31-40.

${ }^{96} J$ Joseph. F. O’Callaghan, El Rey Sabio, pp. 46-47: "Alfonso X reclamaba el ejercicio y disfrute en su propio reino de todos los derechos que el derecho romano atribuía al emperador. Al declarar que era Vicario de Dios en su propio reino, afirmaba que su autoridad provenía directamente de Dios, sin intermediario alguno, ya fuese el papa o el emperador. La titulación real que le proclamaba como 'rey por la gracia de Dios'era un continuo recordatorio de esta especial relación y un ejemplo de la concepción medieval del origen divino de la monarquía".

${ }^{97}$ Sobre las consecuencias del vicariato divino para la caracterización del poder real según el De Preconiis: Castro, Las ideas políticas, pp. 521-526.

${ }^{98}$ Así queda reflejado en el fragmento cronístico siguiente en el que se recogen las palabras dirigidas por el infante don Sancho al rey Alfonso X en el momento de su definitiva ruptura: "Señor, non me fecistes vos, mas fizome Dios, é fizo mucho por me facer, ca mato á un mi hermano, que era mayor que yo, é que era vuestro heredero destos reinos, si él viviera más que vos; é non lo mató por al, sinon porque lo heredase yo despues de vuestros dias". Crónica de Alfonso $X$, cap. LXXV.

${ }^{90}$ Las relaciones del rey con los súbditos en el De Preconiis, Ibid. pp. 526-541. 
evidente que Sancho IV trató de dar un paso más allá con respecto a las enseñanzas de su preceptor, en cuanto a los efectos autoritarios que podían deducirse del origen divino de la realeza, pues, además de plasmarse con todo detalle esta teoría política en los Castigos, abundará en los deberes de servicio de los súbditos hacia el rey, evitando aludir a ese rasgo limitador que quedaba reflejado en el fragmento de Gil de Zamora ${ }^{100}$. En cualquier caso, en los propios textos legislativos alfonsinos había materia más que suficiente para que, a la vez que se encontraba justificación a la falta de mediaciones entre Dios y el poder rey, éste asumiese una posición de irresponsabilidad por sus acciones frente a cualquier autoridad terrena ${ }^{101}$. Tal planteamiento se lleva a sus máximas consecuencias al entender que el rey preexiste al reino ${ }^{102}$, tal como queda reflejado en la imagen del rey

\footnotetext{
100" Temiendo el home á Dios, que es señor sobre todo lo de ayuso, ha de temer á su rey, que tiene lugar de Dios en la tierra, en aquel regno en que lo él pone, é por eso la cosa que el home quiere encarescer ante la pone en lo mas que en lo menos; ca en lo mas descende á lo menos, é de lo menos non puede sobir á lo mas. Por ende dice el apóstol: 'Temed á Dios que 'es señor sobre todo' é de allí descende á los reyes el temer, é á aquellos que tienen los oficios 'de Dios. Demás, luego declara aquella palabra, é dice ansí: 'honrad al rey'.Tres cosas son las que al rey deben facer sus vasallos sobre todas las otras, las cuales son estas: la primera, amarle bien derechamente é guardarle fieldat, é verdat, é lealtad. La segunda, honrar la su persona en sú mujer é sus fijos, é en su estado, é en su casa. La tercera, temerle mas de léjos que de cerca, ca por este temor se guardan los homes de errar contra él, é se guardan de non errar en las otras cosas que deben guardar para non caer en el mal". Castigos e documentos del rey don Sancho (BAE, LI), cap. X, p. 106.

101 Ási se ha sabido observar, creo que con lucidez, por algún aútor especialmente atento a las implicaciones políticas de la legislación alfonsina: "Afirmar que el poder -cualquier poderproviene de Dios era en el medievo un lugar común. Lo que se discutía con calor era el modo de transmión (y recepción) de dicho poder. Para Alfonso X no ofrece duda que el poder temporal que ostenta procede directa e inmediatamente de Dios, y que es Dios quien se lo ha transferido sin la menor intervención de eventuales intermediarios. Así pues, ni el Pontífice, ni el Emperador, ni la comunidad se lo han conferido, ni han tenido ocasión, por ende, de reservarse la titularidad o el ejercicio de porción alguna del mismo. El monarca ha recibido la potestad regia en su integridad, y únicamente a Dios 'es tenudo de dar cuenta de lo quél dexó en guarda'. Con otras palabras: el rey no es deudor de ninguna instancia humana y es irresponsable en la tierra. Aún más, el rey no sólo no es una derivación de la comunidad, sino que 'el pueblo' tiene en aquél su 'comienzo'". Benjamín GonZález Alonso, Poder regio, cortes y régimen político en la Castilla bajomedieval, en "Las Cortes de Castilla y León en la Edad Media", II, Valladolid, 1988, p. 208

102"O sea que, en opinión de Alfonso X, el monarca preexiste al reino en cuanto tal reino $y$ su presencia es la que en cierto sentido lo modela y aglutina, le infunde entidad y lo constituye como comunidad diferenciada. No, no es una interpretación aventurada. El Espéculo asegura que el rey 'es mayor sobre todo su regno por quien todos los del regno reçiben dono de Dios en ser una cosa' y que 'el regno lieva nonbre del rey, ca por el rey es dicho regno'. ¿Es imaginable una exaltación más rotunda del poder regio, de su posición ante el reino y de su inconcusa superioridad'?". GONZÁlez AlONSO, Poder regio, Cortes y régimen político, p. 208 .
} 
como alma del pueblo, según cómo se expresa en el Espéculo, afirmándose con ello que es el rey quien da vida al reino ${ }^{103}$.

Por si el origen divino no asienta aún con suficiente solidez las aspiraciones de incontestabilidad que se pretende para el poder regio y que quedan plasmadas en textos legislativos, doctrinales, así como en fórmulas diplomáticas y en la retórica propia de la historiografía de la época, la equiparación entre corte celestial y corte regia aporta un refuerzo añadido $^{104}$ que se completa con la implicación de Dios mismo como garante de los derechos regios ${ }^{1115}$. Dentro de esta tendencia a la intepretación más autoritaria del poder regio a partir del principio de su origen divino, con todas las connotaciones ideológicas que éste podía conllevar, la paulatina sustitución del modelo cristocéntrico (el rey vicario de Cristo), por el modelo teocéntrico (rey vicario de Dios), que ya se apunta en los textos legales alfonsinos y que se potencia definitivamente con Sancho IV, puede valorarse como indicio de búsqueda de nuevos matices expresivos que permitan la ampliación de las formulaciones más autoritarias, lo que es un hecho bastante característico del monarca recién citado ${ }^{106}$.

Uno de los rasgos más típicos de la concepción de una monarquía de origen divino, cuyas implicaciones políticas se expresaron con toda claridad con Alfonso $\mathrm{X}$ y que se vieron potenciadas, en cuanto a su formulación retórica, por Sancho IV es que siempre se evitó que ese origen divino supusiera cualquier forma de control o de fiscalización de la Iglesia sobre el poder real, bien fuera por mediación del papa o de los obispos ${ }^{1177}$. Por el contrario, la monarquía sacó consecuencias de cara a justificar sus derechos de intervención sobre la Iglesia. Así, se reclamó la posibilidad de exigir de la colaboración de la espada espiritual para que acudiera en ayuda de la temporal cuando ésta lo necesitase. En contrapartida, el rey debería estar

\footnotetext{
103" Ca es el alma del pueblo, ca asi como el pueblo vive por el alma, asi el pueblo vive por el rey". Espéculo. II, 1, 4

${ }^{104}$ Fuero Real. I. II, 2.

105 "Et pues que los reyes deste señor e deste rey habemos el nombre. e dél tomamos el poder de facer justicia en la tierra. e todas las onras, e todos los bienes dél nacen, e dél vienen. e él quiso guardar los nuestros derechos", Fuero Real, lib. IV, tít. V, ley IV.

${ }^{106}$ Sobre la posible importancia de esta sustitución de la fórmula cristocéntrica por la teocéntrica, que ya fue advertida por Kantorowicz, pueden verse algunas puntualizaciones para el caso castellano en mi Fundamentos ideológicos, pp. 58-60.

${ }^{1177}$ Véase una apreciación en este mismo sentido de Manuel GonzÁlez JIMÉnEZ. Alfonso X, 1252-1254, "Corona de España. Reyes de Castilla y León". Palencia, 1993. pp. 197-198
} 
atento a guardar los derechos de la Iglesia, es decir, sus tradicionales privilegios, franquezas y libertades; propiciar las actividades religiosas encomendadas a la Iglesia y acudir, en caso de necesidad, y en justa reciprocidad, en ayuda de la espada espiritual cuando así fuera preciso. En definitiva, todo apuntaba a que la posición gubernativa del rey quedaba fuera del ámbito de acción y de control de ningún poder espiritual, mientras que la Iglesia no estaba exenta de ser utilizada como instrumento político de la realeza. Todo ello era ciertamente compatible con que en la ideología del poder real trascendiese, en definitiva, un efecto de reforzamiento para la posición de la Iglesia en la sociedad, puesto que era en principios de origen eclesiástico y religioso en los que se estaba basando, de los que, en lo moral y doctrinal, se deducían mensajes característicos de la fe cristiana, por lo que nada de ello podía ser contrario a prestigiar socialmente a los eclesiásti$\cos ^{108}$, lo que debió de contribuir a la asociación de intereses entre monarquía e Iglesia. Pero nada de esto podía traducirse automáticamente en un protagonismo político eclesial que fuera más allá de lo que el monarca considerase convienente al pro comunal del reino, del que el rey era intérprete principal, cuando no único. Todo el sistema ideológico garantizaba que las funciones políticas de la Iglesia eran el resultado de la voluntad y de la conveniencia del rey, lo que se hallaba repetidamente implícito en el discurso ideológico de la propia monarquía.

\section{ORIGEN DIVINO, UNCIÓN REAL Y MONARQUÍA SAGRADA}

Es en el contexto del origen divino de la realeza y de sus implicaciones políticas donde cabe situar uno de los rasgos utilizados para caracterizar, por su presencia o ausencia, a las realezas europeas, la unción real, aspecto que, en todo caso, a mi modo de ver, no puede ser determinante de lo que sí entiendo que constituye un rasgo decisivo a la hora de configurar la ideología del poder real: la divinización de la realeza. Es así que, sólo entendiendo la unción como un rasgo subsidiario y no imprescindible del

${ }^{108}$ Algunas puntualizaciones al respecto en: Maurizio TULIANI, La idea de reconquista, p. 
proceso de divinización de la realeza ${ }^{109}$, respecto del cual sólo actúa como medio de exteriorización o de comunicación del mismo, no como su causa, debiéndose, por tanto, distinguir lo políticamente esencial de lo accesorio $^{110}$.

Con cierta frecuencia, se ha tendido a caracterizar la realeza castellana a partir de su falta de ritos litúrgicos de acceso al trono, y cuando, ocasionalmente, éstos estaban presentes, se los ha minusvalorado por su falta de sistematización ${ }^{111}$. Sin embargo, a la vez que se tenían en cuenta, por su ausencia o por su falta de tradición, los aspectos de índole ceremonial como elementos relevantes para definir lo anómalo de la realeza castellana, se obviaba, en cambio, el rasgo esencial sobre el que se sustenta la ideología del poder real en la Castilla bajomedieval, tal como sucede en el resto de las monarquías occidentales de la época: su origen divino. Es de aquí de donde, en cada contexto histórico, se sacaban las consecuencias decisivas para

\footnotetext{
${ }^{109}$ Entendiendo como tal divinización la legitimación de las atribuciones y funciones del poder real por su origen divino, pudiéndose establecer, según cada contexto, matizaciones concretas, tal como se verá, para este principio ideológico.

${ }^{110}$ Tal enfoque de la cuestión no es ni mucho menos una originalidad hispánica. En el marco del siglo XIII, este carácter secundario, cuando no irrelevante, de la unción en el proceso de legitimación del poder del emperador o del rey, formaba parte de una postura perfectamente reconocible entre canonistas y maestros de las más prestigiosas universidades europeas vinculados a las corrientes dualistas opuestas a las interpretaciones hierocráticas que respaldaban las pretensiones pontificias de control político sobre emperadores y reyes (véanse más adelante las referencias a esta distinta interpretación entre canonistas y maestros universitarios de la época sobre el significado político de la unción). Como, en otros muchos aspectos de la caracterización política del poder real en los reinos hispánicos bajomedievales, no estamos en presencia de una excepcionalidad que no pueda ser entendida dentro de lo que es la civilización occidental. en la que, para un mismo problema, en este caso de índole política (¿cómo se legitima el poder real?"), no cabía una sola respuesta, sino que la variedad de referentes intelectuales, por un lado, y la valoración de los intereses en conflicto, por otro, ofrecía alternativas diversas, sin deber ceñirse, por tanto, a una línea única, con marchamo de modelo. Creo que, teniendo en cuenta este planteamiento, hubieran podido ahorrarse algunas observaciones y valoraciones de intención, a mi modo de ver, francamente extemporáneas y carentes de fundamento comprobable. por lo que tienen de suposición de intenciones, como las recogidas con respecto a diversos historiadores españoles en LINEHAN, Histony and historians, pp. 195-196, 409-410, 429, entre otras.

"'Manifestación de esta valoración fundamental, para la caracterización de la realeza castellana, que no comparto, de la ausencia de uso sistemático de la unción y de la taumaturgia en Castilla puede encontrarse en: Téffilo F. RuIz. Une royauté sans sacre: la monarchie castillane du Bas Moven Age, "Annales. E.S.C.", 39 (1984), 429-453; Peter LineHan, History and Historians of Medieval Spain. sobre todo, caps. 12, 13 y 14 y Adeline RUCQUOI, De los reyes que no son taumaturgos: los fundamentos de la realeza en España, "Relaciones. Estudios de Historia y Sociedad", XIII (1992), pp. 55-83, aunque en este último caso los términos España y Castilla son utilizados por la autora indiscriminadamente, ya que los contenidos de trabajo se refieren a Castilla, a pesar de la dimensión peninsular que se pretende dar a las conclusiones.
} 
otorgar al poder regio aquellos atributos y funciones determinantes de su poder y que, según el caso, convenía destacar. Es en la caracterización teocrática del poder real y en su evolución y desarrollo, con o sin unción ceremonial sistemática, con o sin taumaturgia ritualizada, donde reside el fundamento de que un monarca encuentre base para fundamentar determinadas apropiaciones en cuanto a la capacidad de mando, que son las que acaban describiendo lo que es el horizonte potencial de sus pretensiones políticas $^{112}$.

En el contexto de la época, para cualquier realeza podía ser aceptable, incluso imprescindible ${ }^{113}$, la integración del discurso teológicoeclesiástico en el discurso propagandístico del poder real, extrayendo argumentos favorables a sus pretensiones de incontestabilidad. Sin embargo, no podía ser del mismo modo aceptable en todos los casos, ni en todo momento, atendiendo a las circunstancias históricas de su propia evolución plurisecular, unidas a las circunstancias particulares presentes en el comienzo de cada reinado, proyectar esa misma ideología en una imagen ceremonial de la que se podía deducir alguna forma de sometimiento o dependencia del poder real respecto del eclesiástico, como consecuencia del monopolio que sobre la sacralización disfrutaba el clero.

\footnotetext{
1'Podria pensarse. tal como, por ejemplo, ha manifestado el prof. LINEHAN en su Histon and the Historians of Medieval Spain. que esta "secundarización" o subsidiariedad de la unción y la taumaturgia frente al rasgo del origen divino de la realeza sólo se puede entender en quien pretende una especie de "occidentalización" forzosa del caso castellano. Assí podría deducirse de buena parte de las referencias que el citado autor hace de fragmentos míos que aparecen reproducidos descontextualizados y amputados. Io que facilita mucho su crítica. De este modo, son repetidamente interpretados en un sentido que poco o nada tiene que ver con su sentido original produciendo la consiguiente trivialización de alounas de mis posiciones. Debo aclarar que mi caracterización ideológica del poder regio en la Castilla bajomedieval siempre. a pesar de lo que el profesor Linehan pretenda deducir intepretando alguna frase mía del modo más conveniente para su crítica, no para su comprensión, ha consistido en optar por dar atención preferente a la constatación de sus contenidos como monarquía de derecho divino, en la que la ausencia o presencia de la unción no tenía valor decisivo. En cualquier caso, esta postura de relativización de la unción en el contexto de la dimensión teocrática del poder real no puede considerarse como una especie de salida de emergencia para historiadores atribulados por la insuficiente europeización de lo hispánico, tal como pretende, a partir de uno sus peculiares juicios de intenciones el prof. Linehan. Por poner un ejemplo, una postura caracterizada por entender el concepto de monarquía sagrada. basada en el uso del acto litúrgico de la unción. como de valor política e históricamente secundario con respecto a conceptos como el de monarquía de derecho divino o como el de monarquía absoluta fue defendida en su día por el profesor de Historia del Derecho de la Universidad de París, miembro del Institut. Francois Olivier Martin, en esta ocasión. pensando en el caso concreto de la monarquía francesa. tal como puede verse en: Michel DEVĖZE. La doctrine d'Olivier Martin sur la monarchie française de droit divin. en "Le sacre des rois". París, 1985. pp. 243-248.

${ }^{113}$ Véase a este respecto la obra citada más arriba de Sophie Menache.
} 
El origen divino de la realeza castellana no se había puesto en cuestión en el ya largo tiempo que había transcurrido desde que Fernando I estableciese el uso común del "rex gratia Dei", a pesar de la falta de utilización de una ceremonia de unción real. Esta experiencia histórica podía darle a Alfonso X la suficiente confianza como para que, teniendo además en cuenta la más amplia dimensión autoritaria que ahora se proponía extraer de la ideología vinculada a la monarquía de derecho divino, no pareciese ni necesario ni coherente recurrir a tal recurso ceremonial ${ }^{114}$. A ello se unía

\footnotetext{
${ }^{114}$ A partir de la utilización descontextualizada de una frase de mi Iglesia y poder real en Castilla, p. 58 se ha pretendido, dedicando amplia atención a ello, atribuirme la afirmación de que la unción real habría persistido en Castilla sin interrupción desde los visigodos hasta Juan I (véase LINEHAN, History and the Historians, p. 123 y sigs. 123 y 428-430). La interpretación del prof. Linehan es el resultado de aislar una frase de lo que la precede y de lo que la sucede. $\mathrm{Si}$ se hubiera tenido en cuenta lo que precedía a la frase, se hubiera podido comprender que lo que trataba de establecer era una imagen de contraste entre el hecho de que en los reinos hispánicos existieran precedentes de unción en la época visigoda, como forma de manifestación de las relaciones monarquía-Iglesia en el momento del acceso al trono y, en cambio, la forma de expresión de tales relaciones que persistió en Castilla no fue ésta, sino los juramentos de los monarcas, con presencia inevitablemente eclesiástica o, en su ausencia (por eso digo en mi texto bajo una u otra fórmula) las confirmaciones de los privilegios eclesiásticos que, en definitiva, venían a ser una forma de compromiso juramentado del rey con su clero, o los homenajes recognoscitivos, estudiados por Hilda Grassotti. Por ello, el contenido completo del texto que debió haber reproducido el prof. Linehan en su obra para no provocar una percepción torcida de lo que se trataba de decir originalmente hubiera sido el siguiente: "Desde fines del siglo XII y a lo largo del siglo XIII, el que los monarcas de los reinos occidentales hicieran juramento con carácter sagrado ante los representantes de su Iglesia en el momento de su coronación fue algo bastante generalizado (...) Para el caso de los reinos hispánicos, si ya existía (puede entenderse con mayor claridad diciendo, pues en este sentido utilizaba el "si ya", "aunque ya existía...") un precedente de unción regia en la Monarquía visigoda, este ceremonial [juramentos o confirmaciones de privilegios clericales] persisitió, bajo una u otra fórmula, hasta decaer en la Baja Edad Media; siendo Juan I el último monarca que siguió esta tradición en su coronación". En el momento en que redactaba esto, 1983, si bien el texto sólo se publicó en 1988 , todavía el procedimiento ceremonial castellano para tiempos posteriores a Juan I no había sido objeto de estudio sistemático, tarea que realicé yo mismo en mi Ceremonias de la realeza. Propaganda y legitimación en la Castilla Trastámara, Madrid, 1993, lo que me ha permitido comprobar la persistencia del protagonismo de los juramentos reales en presencia de eclesiásticos en tiempos posteriores a Juan I. No obstante, por si había alguna duda intepretativa de mi visión del asunto, la lectura de la página siguiente a la del fragmento reproducido por el prof. Linehan, ignorada por éste con relación a la citada frase, en la que aludo a los rasgos ceremoniales de cada una de las entronizaciones desde Alfonso X hasta Alfonso XI, hubiera sido suficiente para darse cuenta de que no me podía estar refiriendo a la unción real. Del mismo modo, la mezcolanza de opiniones mías expresadas en trabajos en las que se abordaba el problema de la unción en el plano de la ideología frente a otros textos en los que lo hacía en el marco de los problemas ceremoniales da lugar a que el prof. Linehan desvirtúe el sentido de mis opiniones, pudiendo ironizar así, a partir de ellas, en términos críticos. Es lástima que una obra, como la del prof. Linehan, en la que se exhibe tanta erudición, refleje también tanto empeño en trivializar las opiniones y puntos de vista de tantos historiadores, como si las investigaciones de su autor precisasen de la ridiculización de las ajenas para hacerse más apreciables. Una valoración, a mi modo de ver, muy ecuánime de History and Historians en Miguel Angel LADERo QueSADA, Sobre la historia y los historiadores de la España Medieval,
} 
que la particular atención que el Rey Sabio dedicó al conocimiento del pasado histórico de los reyes precedentes y, en particular, de los visigodos, le ofreciese la lección de que la unción practicada por éstos no pudiera considerarse como una garantía de incontestabilidad para el poder real. El ejemplo de un rey visigodo tan señalado como Wamba, ungido y depuesto, con particular protagonismo de unos eclesiásticos convertidos en vigilantes de la legitimidad regia, seguramente lo tendría bien presente ${ }^{115}$.

En el análisis que se ha trazado en el apartado anterior, al considerar las referencias ideológicas sobre las que se asentaba el concepto de monarquía de derecho divino que caracterizaba la realeza castellana, y que se vio tan decididamente potenciado tanto por Alfonso X, como por Sancho IV, ya se advertirían las importantes consecuencias políticas que de tal concepto se pudo sacar desde la propia monarquía, destacando la idea de su autonomía con respecto de cualquier otra instancia de poder, tanto temporal como espiritual, como consecuencia de la directa vinculación entre realeza y divinidad. En tales circunstancias, es fácil comprender que los monarcas evitasen cualquier forma de representación que pudiera ofrecer una imagen de sometimiento o dependencia al poder eclesiástico como podría deducirse con la ceremonia litúrgica de la unción ${ }^{116}$.

Problema esencial a resolver es si los reyes castellanos, al renunciar al uso ceremonial de la unción, a la vez que, ciertamente, evitaban una posible lectura reductora de su autonomía política que parecía quedar, a través de la unción, bajo la fiscalización legítima de la Iglesia, no renunciaban también a la protección particular que al poder regio le dispensaba el hecho de haber sido reconocido como cosa sagrada y que convertía en sujeto de sacrilegio a quien actuase en su contra. Me parece que esta es una cuestión de la que Alfonso X tuvo conciencia y a la que, tal como veremos,

"Boletín de la Real Acdemia de la Historia", CXCII (1995), pp. 103-117.

${ }^{115}$ Un análisis meticuloso sobre la visión histórica del reinado de Wamba en una obra cronológicamente tan próxima a Alfonso X como De Rebus Hispanie del arzobispo toledano Rodrigo Jiménez de Rada puede verse en: LINEHAN, History and the Historians, pp. 384 y sigs.

${ }^{116}$ Así se ha advertido, creo que acertadamente, pensando en el caso concreto de Alfonso X en O'Callaghan, El Rey Sabio, pp. 48-49: "En lugar de permitir que estas ceremonias pudieran ser vistas como expresión de la superioridad de la autoridad eclesiástica, Alfonso $\mathrm{X}$ subrayó la dependencia directa de su monarquía del mismo Dios, sin la mediación del papa o de un arzobispo". 
trató de dar respuesta, siendo posible referir sus efectos al conjunto de la realeza bajomedieval castellana.

La hipótesis explicativa que ahora me propongo exponer constaría de los siguientes puntos:

1) Que Alfonso $X$ fue consciente de que, dentro de su proyecto político, era necesario rodear a la realeza que él encarnaba de una cierta connotación de sacralidad, valorando en algún momento la posibilidad de que para ello podía llegar a ser conveniente la incorporación de una ceremonia de unción regia.

2) Que acabó desechando tal solución, seguramente por considerar todas sus connotaciones contraproducentes para el poder regio que se han señalado anteriormente.

3) Que, no obstante este rechazo de la unción, sin renunciar a sus pretensiones iniciales, encontró una vía alternativa, con efectos jurídicos y políticos, para proveerse de la sacralidad que precisaba y en la que se evitaban las limitaciones a su autonomía que podía conllevar la incorporación de la unción.

4) Que esa vía alternativa abierta por Alfonso $X$ cuajó, siendo conocida e incorporada por los reyes castellanos a la panoplia de sus recursos propagandísticos y legitimadores, teniendo una larga vigencia, de la que se pueden encontrar testimonios particularmente relevantes en contextos de crisis de legitimidad y de conflicto político, experimentándose en el contexto de las crisis políticas del siglo $\mathrm{XV}$, y a partir de la aplicación de soluciones alfonsinas, una utilización particularmente intensa de la fórmula del Rey Sabio.

Veamos los testimonios sobre los que cabe fundamentar tal hipótesis.

1) Alfonso $X$ fue consciente de que el concepto de origen divino de la realeza debía proyectarse en una apropiación por parte de ésta de rasgos sacrales. Para ello, trató de impulsar, en el plano ideológico, una dialéctica sacral propia que se fundamentaba en la deducción de la vinculación entre monarquía y divinidad de efectos automáticos de sacralización, sin mediación eclesiástica, para aquélla. Esto sería, por otra parte, desde la perspectiva de los mecanismos intelectuales aplicados, el efecto de lo que, a veces, se entiende como secularización, es decir la reinterpretación política de principios teológicos, siendo afectado por tal procedimiento el propio 
concepto de sacralidad ${ }^{117}$. A lo largo de la Primera y Segunda Partida se pueden encontrar manifestaciones paradigmáticas de tal planteamiento ${ }^{118}$. De este modo, se ponen las bases para desarrollar todo un campo semántico en el que la apropiación de lo sagrado por el poder regio resulta factible, permitiendo crear, a partir de ello, mensajes precisos de sacralización del poder regio políticamente utilizables, en términos de propaganda y de legitimación, y, a veces, eficaces. Baste ahora solamente apuntar esta idea, que habrá de retomarse en varios puntos del desarrollo de esta hipótesis, más adelante, para aplicarla de forma concreta.

Nos centraremos en el manejo de la que se considera como la más primitiva de las versiones de la Primera Partida, la conservada en el British Museum y editada por el prof. Arias Bonet ${ }^{119}$. En esa versión más antigua de la Primera Partida hay un fragmento, que ha llamado la atención de algún

\footnotetext{
${ }^{117}$ Tal planteamiento disponía, en el contexto de la época alfonsina, de apoyos teóricos reconocibles, a los que ya hizo alusión Kantorowicz, al señalar que, frente al grupo de los canonistas hierocráticos, partidarios de la ampliación del poder pontificio frente al real y al imperial, "el otro grupo de canonistas, los 'dualistas', que estaban a favor de un equilibrio de los dos poderes universales, mantenía que el poder imperial provenía sólo de Dios a través del acto de elección. El argumento típico de estos canonistas 'dualistas' del siglo XII y principios del XIII era que los emperadores existian antes de que hubiese Pontífices, y que los emperadores de épocas anteriores tenían poder incluso sin la consagración, porque, en cualquier caso. todo poder venía de Dios". (Los dos cuerpos del rey, pp. 304-305). En esa misma línea se manifestaría más tarde Juan de París, con motivo de que "declarase abiertamente que los reyes eran igualmente reyes sin la unción, y que en muchos países cristianos (aludiendo como ejemplo de ello a los reinos hipánicos) las unciones de reyes ni siquiera se practicaban". (ibid. p. 308). En efecto, comentando la obra de Juan de París, Jean Leclercq. con relación al problema de la unción real, este autor ya señaló cómo la unción real no tiene un valor esencial, puesto que no es por la unción cómo reciben el poder, cuyo origen sólo podía hallarse en Dios mismo, tal como se planteaba en la ideología alfonsina. Así la unción tan sólo tenía el valor accidental de una imagen que no aportaba caracterización esencial alguna al poder real. Véase Jean LeclercQ, L'idée de la royauté du Christ au Moyen Age. París, 1959. pp. 162-163.

${ }^{118}$ En el mismo comienzo de las Siete Partidas se puede advertir ya una expresión de esa asociación directa y automática entre Dios y divinidad de la que se sacaron fructíferas consecuencias políticas. Así, cuando se dice: "Onde nos, por toller todos estos males que dicho auemos, fiziemos estas leyes que son escriptas en este libro, a seruicio de Dios e a pro comunal de todos los de nuestro sennorio (...) Onde quien contra esto fiziesse, dezimos que errarie en tres maneras. La primera contra Dios cuya es cumplidamientre la iusticia e la uerdat por que este libro es fecho, la segunda contra sennor natural, despreciando so fecho e so mandamiento" (Part. I. prólogo). Obsérvese la trasposición que se está produciendo de la justicia y ley divinas a la justicia y ley regias. Io que permite deducir que el incumplimiento de las leyes del rey es un acto contra Dios, en definitiva, tal como se desarrollará más adelante en la Primera Partida. un sacrilegio, un acto contra sagrado. Es fácilmente comprensible la enorme expectativa de utilización política que permite esta asociación entre divino y regio.

${ }^{119}$ Juan Antonio ARIas Bonet. Primera Partida (Manuscrito Add. 20.787 del British Museumil). Valladolid, 1975.
} 
autor, en el que se alude a la unción real ${ }^{120}$. Teniendo en cuenta que ese fragmento no reaparece en las versiones posteriores de la Primera Partida, el prof. O'Callaghan ha deducido, creo que con buen criterio, que el rey y sus colaboradores valoraron la posibilidad de incorporar a la realeza castellana la ceremonia de la unción, pero que desecharon tal solución ${ }^{121}$. Estando plenamente de acuerdo con esta interpretación, me gustaría dar un paso más adelante y reflexionar sobre el hecho de que tal fragmento no cuajase, tal como se anunciaba, en un ceremonial de la unción, desapareciendo incluso en las redacciones posteriores, pero teniendo, en cambio, un cierto efecto inspirador a largo plazo ${ }^{122}$.

Tal como se plantean las condiciones de acceso al rito de la unción, parece claro que el monarca se preparaba el terreno para que su acceso al mismo, en caso de que le conviniese o no le quedase más remedio que someterse a él ${ }^{123}$, pudiera producirse sin dificultad y sin aceptar por ello compromisos excesivos. La condiciones que debe reunir un monarca para ser ungido, tal como se dice en la ley, son tener en este mundo el lugar de Cristo para hacer justicia y derecho, condición indiscutible en el caso de los reyes castellanos, tal como proclamaban en toda ocasión, y, además, soportar los sufrimientos que les pudieran venir "por onrra e por exaltamiento de la cruz". Tal condición también era objeto de exhibición por un monarca que presumía de su dedicación a la lucha contra el infiel y de su

\footnotetext{
120"E porque los reyes christianos tienen so logar en este mundo para fazer iusticia e derecho, e son tenudos de sofrir todo encargo et afán que les auenga por onrra e por exaltamiento de la cruz, por esso los ungen en este tiempo con olio sagrado en el ombro o en el espalda del braço derecho, en sennal que toda carga e todo trabaio que les abenga por esta razón. que lo sofran con muy buena uoluntad e lo tengan cuemo ligero, por amor de nuestro sennor Ihesu Christo que dixo en el euangelio que el so yugo era blando, e la su carga ligera. E esta unción se deue fazer. segund dize en el segundo libro". Partidas, I, IV, ley XIII.

121 "Evidentemente, el rey y sus colaboradores estaban pensando en incorporar en el código las ceremonias de la unción real, pero ninguna de las versiones conservadas de las 'Segunda Partida hace referencia a la unción. Por tanto parece que no llegó a elaborarse el ritual de la unción". O'Callaghan, El Rey Sabio, p. 47.

12-Referencias a este pasaje en Peter Linehan. History and Historians, pp. 439-444, aunque desarrollando perspectivas de valoración del texto distintas de las que aquí se recogen.

${ }^{123} \mathrm{Me}$ pregunto si quizá se incluiría esa referencia a la ceremonia de la unción pensando también, no sólo en el caso del reino de Castilla. sino en el imperio, pretendiendo crear unas condiciones de interpretación de la unción lo más favorables para el ungido en cuanto a las exigencias y compromisos, valorando la posibilidad de que, en caso de ser elegido emperador, no tuviera más remedio que someterse a ella. Sobre la relación entre el comienzo de la redacción de las Partidas y el fecho del Imperio: GonZÁlez JimÉnEZ. Alfonso X. p. 252. con referencias bibliográficas sobre las distintas posiciones de los especialistas al respecto.
} 
posición como cabeza visible de una intensa actividad guerrera revestida de todas las connotaciones ideológicas ${ }^{124} \mathrm{y}$, a veces, gracias a las concesiones pontificias, también de las económicas ${ }^{125}$ propias de la cruzada. Pero, además, hay que llamar la atención sobre el hecho, seguramente no casual, de que se aluda a la cruz, no a la Iglesia ni a sus principales ministros, como, por otra parte, hubiera podido esperarse de no plantearse esta redacción con lo que me parece que tenía intencionalidades políticas evidentes. De este modo, en primer lugar, en el texto se establecen unas condiciones de acceso a la unción que el rey castellano cumple perfectamente. En segundo lugar, como correlato de lo que acabo de decir, quedaba abierta la puerta para que, en el plano de la propaganda político-ideológica, el rey pudiera pretenderse como rey ungido, no por el desarrollo de un acto ceremonial, sino por el origen divino de su poder y por su función de defensor de la cruz. En tercer lugar, en caso de asumir, finalmente, someterse a tal ceremonia de ungimiento, tal como quedaba anunciado para ser objeto de desarrollo en la Segunda Partida, el rey estaba en condiciones de afrontar tal hecho sin que ello le supusiera compromisos explícitos con la Iglesia, quedando en este punto todo reducido a ese etéreo "onrra e exaltamiento de la cruz".

No obstante, este anuncio de ceremonial de unción no se concretó en la Segunda Partida, al menos que haya existido alguna versión, anterior a las conocidas de este texto, en que se desarrolle tal aspecto, lo que, hoy por hoy, no es comprobable. ¿Por qué no cuajó este proyecto de unción? Podrían alegarse, desde mi punto de vista, varias razones. En primer lugar, porque, a pesar de todo, resultaba inevitable que la unción supusiera un rito del que se podía deducir alguna imagen de supeditación y de dependencia del rey hacia el clero representado en los prelados oficiantes. En segundo lugar, porque los consejeros de Alfonso X debían saber que Inocencio III había establecido una doctrina precisa sobre el significado de la unción real, en la que, a la vez que se infravaloraban los efectos espirituales de la unción, no faltaban las implicaciones coherentes con los criterios de la teocracia

\footnotetext{
${ }^{12-4}$ Una aportación reciente sobre la la ideología cruzadista en tiempos de Alfonso X en: José M. Rodriguez Garcia. Idea and Realit of Crusade in Alfonso X. Reign Castile and Leon, 1252-1284. en "Autour de la Première Croisade". edic. de Michel Balard, París, 1996, pp. 379-390.

${ }^{125}$ Enumeración cronológica de las concesiones pontificias de cruzada para la recaudación de la correspondiente limosna para luchar contra el Islam en la Península y referencia a los abusos reales en tal materia en mi Iglesia y poder real, pp. 128-129.
} 
pontificia, de la que se deducían depedencias respecto del pontificado que, seguramente, producirían, al ser valoradas, todo tipo de inquietudes en el ánimo del monarca ${ }^{126}$. Que tales circunstancias debieron ser objeto de consideración me parece más que probable, si tenemos presentes las, a mi modo de ver, atinadísimas observaciones que recientemente ha hecho con relación a este mismo problema para el reino de Aragón el prof. Palacios Martín ${ }^{127}$. A todo ello se unía, y esto es lo más importante, de cara a la continuación en el desarrollo de nuestra hipótesis, que el monarca y sus colaboradores, en el contexto de la propia redacción de la Primera Partida, instrumentaron referentes sacralizadores del poder regio que, a la vez que se mostraban suficientes, en principio, para sus objetivos políticos, evitaban todas las inquietudes que una ceremonia de la unción, con sus rasgos rituales y con sus posibles implicaciones interpretativas, podía tener.

2) No hay dato alguno conocido que permita suponer que Alfonso $\mathrm{X}$ incorporara la opción de la sacralización real de carácter ceremonial que quedaba reflejada en el fragmento señalado de la Primera Partida. La promesa relativa al desarrollo de sus rasgos rituales no se plasma en la

\footnotetext{
${ }^{126}$ Véase al respecto Kantorowicz. Los dos cuerpos, pp. 302-304: "El papa Inocencio III les otorgó a los obispos la unción con crisma y de cabeza, pero le negó radicalmente el mismo privilegio al Príncipe. Sus argumentos resultan interesantes no sólo por la desvalorización del ceremonial litúrgico, sino también porque revelan una inversión completa de la antigua idea de realeza cristocéntrica y a semejanza de Cristo (...) en aras de recalcar la diferencia con la unción de Cristo, la unción del Príncipe se trasladó de la cabeza a los hombros y brazos, y se ejecutó no con crisma, sino con un óleo menor. 'Sin embargo - fragmento de la decretal pontificia-la unción sacramental de la cabeza del obispo se ha preservado porque en su oficio él. el obispo, representa la persona de la Cabeza (es decir, de Cristo). Hay una diferencia entre las unciones de obispo y Príncipe: pues la cabeza del obispo se consagra con crisma, mientras que el brazo del Príncipe se alivia con óleo. Que se sepa cuán grande es la diferencia entre la autoridad del obispo y el poder del Príncipe. El rango litúrgicamente inferior de la unción del gobernante se hace patente: se limitaba a un exorcismo ligeramente sublimado y a una immunización contra los espíritus del mal. Según la doctrina hierocrática, la unción real ya no confería el Espíritu Santo, aunque los ordines de coronación todavía guardaban esta idea y los canonistas ponderaban todavía sobre si el emperador era o no una persona eclesiástica. Sin embargo, lo principal era que al Princine se le había negado expresamente una imagen o semejanza de Cristo o el carácter de un christus Domini". A todo ello se añade, según comenta el propio autor, reflejando alguna de las glosas a que dio lugar la decretal de Inocencio III, que "técnicamente la palabra 'consacrare' ni siquiera era aplicable a la coronación imperial". Parece evidente que si, como creo probable. Alfonso X tuvo conocimiento de este criterio pontificio. resolviera evitar el recurso a la unción regia, pues, en sus contenidos estaba claramente presente un planteamiento ideológico frontalmente opuesto al que él y sus colaboradores pretendian promover.

${ }^{127}$ Véase. tal como analiza el mencionado autor, la actitud que tomaron los reyes de Aragón. desde Pedro II hasta Alfonso IV, con relación al problema de la unción y a las implicaciones contrarias a sus intereses mayestáticos que ésta podía tener. PALACIOS MARTín, Imágenes y símbolos del poder real en la Corona de Aragón. pp. 216-217.
} 
Segunda Partida, tal como anunciaba. Bien es verdad el carácter postalfonsino de las versiones conocidas de la esta Segunda Partida, pero, a falta de otros testimonios, habrá que concluir que Alfonso X desechó la mencionada fórmula de unción.

3) Rechazada tal posibilidad, en cambio, el monarca no renunció a establecer vías de sacralización de su poder que no tuvieran que pasar por un rito de eficacia política dudosa, cuando no contraproducente. De ello, hay ya textos de la Primera Partida que podrían interpretarse en este sentido y que acaso podrían justificar el que no se llegase a desarrollar el tema de la unción en la Segunda Partida, puesto que el monarca había encontrado alternativas a sus pretensiones sacralizadoras que no pasaban por ofrecer una imagen de pérdida de autonomía con respecto al poder eclesiástico, tal como podía suceder a resultas de la unción.

En el título XVIII de la Primera Partida, relativo a los sacrilegios, me parece que se puede hallar una de las máximas expresiones de la mecánica secularizadora que advertía el prof. Ferrari en el código alfonsino. En el desarrollo del concepto de sacrilegio, como sinónimo de crebantamiento de cosa sagrada, se trata de obtener todos los beneficios protectores que para el poder real se pueden aplicar a partir de su consideración como cosa sagrada, con lo que podía colmarse razonablemente la pretensión de sacralización del poder regio como correlato de su origen divino. Así se señala que "e otrossí es sacrilegio usar sin derecho de cosa que pertenesca a Dios, o a otra cosa qualquier que sea sagrada. Otrossí es dicho sacrilegio el yerro o el pecado que omne faze contra los mandamientos de la Ley de Dios, o contral derecho público, que quier tanto dezir cuemo derecho conmunal que deue cada uno defender e emparar"128. Este planteamiento de incluir cualquier acción contra el derecho público dentro de los actos sacrílegos, considerando el propio derecho público como cosa sagrada, es objeto de mayores concreciones dentro del mismo título ${ }^{129}$, para llegar a sacar la consecuencia, bien conveniente a las pretensiones políticas regias, de que tendría carácter sacrílego todo acto contra las decisiones del

\footnotetext{
${ }^{128}$ Particlas, I, XVIII, 1.

129" Nombre e semeiança de sacrilegio han otras cosas que fazen los omnes o dizen sin derecho e $\sin$ razón e no las llaman ni las dizen de llano sacrilegio, cuemo a las que son dichas en las leyes ante desta, mas son cuemo sacrilegio. E esta manera atal se departe en dos guisas: cal la una se toma por todo pecado que omne faze contra la Ley de Dios. e la otra por todo fecho que omne fiziese traspasando e crebantando el derecho comunal de las leyes seglares, e de los establecimientos de Sancta Eglesia. por que vienen los omnes". Ibid. ley 13.
} 
emperador o del rey ${ }^{130}$, de tal manera que, partiendo de la sacralización de la ley secular por su vinculación a la ley divina, se llega a la de los actos regios y, en definitiva, a la del monarca por su vinculación a la divinidad. Hay que recordar que estos planteamientos fueron objeto de utilización política concreta, tal como quedó plasmado durante la sublevación del infante don Sancho contra su padre, al aplicarse la excomunión contra él y sus seguidores como culpables de sacrilegio ${ }^{131}$.

A través de este desarrollo dialéctico, propio del proceso de secularización del pensamiento teológico característico del momento, el monarca había desarrollado lo que creo que puede interpretarse como una manifestación de que el origen divino del poder real se entendía con base suficiente para proveer a la monarquía del adecuado fundamento para justificar la inviolabilidad de su poder a partir de criterios expresados en clave sacral. Todo ello hacía comprensible que el monarca pudiera entender como justificado que, desde el punto de vista de la caracerización de su poder, éste se interpretase como cosa sacra y él, personalmente, como un rey ungido, como consecuencia de lo anterior.

El carácter tardío del Setenario ${ }^{132}$, probablemente ubicable entre 1282 y 1284 , permite ofrecer un testimonio de valor excepcional de hasta qué punto había llegado la ideología alfonsina en este proceso de llevar a sus máximas consuencias posibles el concepto del origen divino de la realeza hasta llegar a producir un efecto de sacralización autónoma de la misma.

Siguiendo las argumentaciones desarrolladas por Georges Martin con relación a esta obra ${ }^{133}$, Dios es colocado en el origen de la empresa alfonsina, de su poder y de su linaje. Con el Setenario se confirma la tendencia a la expansión de la intervención divina que se refleja en todo el desarrollo de la labor legislativa del Rey Sabio, dando como resultado el

\footnotetext{
130" Traspasando alguno o crebantando el derecho comunal del fuero por que se guían los omnes en los fechos del mundo, faze cuemo sacrilegio. E esto seríe cuemo si alguno contendiesse e porfiasse sobre alguna cosa que ouiesse fecho el Emperador, o el Rey, diziendo a sabienda e sin derecho mal dello, o si dubdasse en ello e lo reprehendiesse diziendo que no es derecho aquello que fizo magar se pudiesse fazer de buena uoluntad o mala". Ibid., ley 14 .

${ }^{1: 1}$ Les Registres de Martin IV (1281-1285), París, 1901, docs. 300 y 479.

13:-Véase al respecto: Jerry R. CRADDOCK. El Setenario: última e inconclusa refundición alfonsina de la Primera Partida, "Anuario de Historia del Derecho Español", 56 (1986), pp. $441-446$

${ }^{133}$ Georges MarTin, Alphonse X ou la science politique ('Septensire', 1-11), "Cahiers de Lingüistique Hispanique Médiévale". 18-19 (1993-1994), pp. 79-100.
} 
reforzamiento de "la asunción del derecho real por el orden espiritual" ${ }^{134}$. En el Setenario quedaría plasmada como primera idea esencial "la naturaleza espiritual de la autoridad real"135. A este proceso de asunción espiritual de poder representado por Alfonso X, se incorpora el propio rey Fernando III, quien es presentado como una especie de "mediador natural entre su hijo y la divinidad"136. Buen ejemplo de este automatismo de relación entre lo divino y lo regio habrá de ser el que se afirme que, ya por el propio nombre del rey, se produzca una correspondencia entre sus siete letras y los siete dones del Espíritu Santo que quedan incorporados al monarca desde el momento en que se le da nombre ${ }^{137}$. Resultado de todo ello es que, de acuerdo con la interpretación que del Setenario ofrece el prof. Martin, Dios mantiene una relación cada vez más sustancial con el poder real ${ }^{138}$.

Esta relación sustancial entre el poder real y la divinidad, con la consiguiente espiritualización de aquél, que se veía anunciada en las primeras versiones de la Primera Partida, ahora alcanza una expresión máxima en el Setenario, ofreciendo una referencia más para comprender la falta de sentido de una ceremonia de unción cuya inexistencia no impide que el rey se presente como investido de todas las cualidades de que le podía proveer aquélla. En este marco, es comprensible que, cuando se hable en el Setenario de unción real, ésta quede referida a la que recibió Cristo, siendo éste de quien los reyes reciben su fuerza para "mantener los pueblos en justiçia e en derecho". De este modo, la fuerza que recibe Cristo a través de

\footnotetext{
${ }^{13.4}$ Ibid. . pp. 93-94.

${ }^{135}$ Ibid. . p. 96.

1.6.lbid.. p. 96.

${ }^{137}$ Ibid.. p. 97.

:38"Ce thème y est lié à celui de la nature spirituelle de la royauté dans la figuration emblématique du couple formé par Ferdinand et son fils Alphonse rapporté analogiquement au couple historique formé par David et Salomon et (avec l'invocation du Saint-Esprit) à celui, dogmatique. du Père et du Fils dans la Trinité. Cette construction, reposant à la fois sur des conceptions manifestes et sur un réseau de rapports implicites, extrêmement cohérente en tout cas, vaut sans doute d'abord par elle-même, en ce qu'elle constitue une des formes les plus achevées de l'idéologie monarchique. Je ne vois pas, avant elle, en Espagne, plus savamment tramés les fondements imaginaires de la clôture spirituelle et naturelle de l'autorité royale - ni plus habilement- représenté, en outre, sur la scène de ce qui, doublement (sous le rapport de la politique et de l'écriture), se présente comme une pratique de lautorité: le livre de lois". Ibid. . p. 98-99.
} 
su propia unción es trasferida al rey en el ejercicio de su poder ${ }^{139}$. Una vez más se viene, así, a mostrar que el rey dispone de la plena protección divina sin recurrir a la unción, sino por los efectos del propio concepto de réaleza de origen divino.

Si esto lo ponemos en relación con el anuncio de un ceremonial de unción regia, tal como se plasmaba en la versión más antigua de la Primera Partida, como se señaló antes, teniendo en cuenta la comparación entre ese texto de comienzos del reinado y este otro, al que ahora me refiero, de fines del mismo, es posible advertir hacia qué tipo de fórmula ha evolucionado el problema de la unción real en la ideología alfonsina. Se ha pasado de la valoración de plantear una posible ceremonia de unción regia, a desechar definitivamente tal opción, para terminar incorporando, ya no en el plano de los recursos ceremoniales de la realeza, sino en el de su retórica ideológica, una fórmula de unción por la que el monarca se convierte en depositario de todos los beneficios de la unción que, como rey temporal, habría recibido el propio Cristo. A la vez que se trata de una evolución perfectamente

\footnotetext{
${ }^{139}$ A esta alusión a la unción real con referencia a Cristo ya me refería en mi Fundamentos ideológicos, pp. 62-63. Mi opinión al respecto fue objeto de crítica por el prof. Linehan que señalaba cómo esta cita a la unción. sin entrar, por su parte, en el análisis del fragmento concreto, se hacía en el marco del tema del bautismo, por lo que no era valorable con respecto a la unción en sentido político. Al hacer esa crítica, el prof. Linehan (History and Historians, pp. 440-441), a la vez que no señalaba cómo esa relación con el bautismo ya la advertía yo (en esta ocasión nó debió considerar oportuno reproducir la frase en la que yo decía "si bien una gran parte de las referencias contenidas en esta obra aluden a la unción que tiene lugar con motivo del bautismo, se encuentran en ella menciones concretas de la unción regia, generalmente, a partir de la utilización del modelo cristocéntrico"), tampoco parecía apreciar las posibilidades de interpretación política de un texto que, teniendo en cuenta lo que se acaba de señalar en las líneas precedentes, siguiendo las observaciones del prof. Martin, y a la vista de lo que el texto concreto dice. evidencia claras posibilidades de valoración ideológico-políticas en el sentido que yo apuntaba en el libro indicado. Para mayor ilustración, el texto al que me refería decía lo siguiente: "Que Ihesu Cristo ffué untado por uerdadero rrey tenporal muestra el ssu nonbre; que Ihesu Cristo en griego tanto quiere dezir commo vntado. Et antiguamiente todos aquellos que eran llamados para sser rreyes auyan a sser vntados. Et él ouo en ssí todo esto: que ffué vntado e dió enxienplo de ssí a los otros rreyes tenporales, que an poder de ffazzer justiçia en las cosas maniffiestas que sson, por que por la ayuda de aquel uerdadero rrey cuyo logar ellos tienen en la tierra ssean enffortalecidos para mantener los pueblos en justiçia e en derecho. Et que los rreyes deuen sser vntados muéstralo Ysayas en nonbre de Ihesu Cristo o dixo: El mio ssagrado Çirio, cuya diestra yo tomé". Setenario, ley LXXXIX, ed. de K.H. Vanderford, p. 155. Si este fragmento se incluye, ciertamente, en el contexto de la explicación del significado que la unción o crisma tiene dentro del bautismo, también me parece, a pesar de la opinión en contra del prof. Linehan. que lo aquí reproducido debe ser tenido en cuenta, tal como puse de relieve años atrás, con relación a los contenidos cristológicos de la ideología política alfonsina y el papel que la referencia a la unción tenía dentro de ese pensamiento en el sentido interpretativo que ahora vengo señalando con relación al papel de la unción regia en la ideología del origen divino de la realeza castellana.
} 
coherente con la experimentada por la ideología alfonsina, deja abiertas unas expectativas de futuro para su aprovechamiento por la ideología política de la realeza que habrá de terminar produciendo efectos constatables antes del término de la evolución bajomedieval.

4) En efecto, procesos dialécticos como el que se acaba de seguir, junto con el desarrollo en orden a establecer consecuencias políticas concretas de la ideología del origen divino de la realeza, supusieron un patrimonio que, profusamente enriquecido en la corte de Alfonso X, fue objeto de aprovechamiento y ampliación en tiempos más tardíos, tal como se puede advertir para el problema concreto de la sacralización del poder regio.

Ya señalé más arriba la voluntad de aprovechamiento político máximo de Sancho IV de la ideología del origen divino de la realeza, todo ello en un contexto de fuerte crisis de legitimidad a resultas de la guerra civil mediante la que accedió al trono. Este contrexto de crisis de legitimidad influiría seguramente en dar particular dimensión litúrgica a su entronización $^{140}$. Pero, aparte de hacer intensa exhibición del origen divino de su poder, Sancho IV no tuvo empacho en calificarse como rey sagrado ${ }^{141}$, lo que daría más verosimilitud al acontecimiento -aunque ciertamente aislado- que describe Alvaro Pelayo y del que se pone él mismo como testigo por el que el rey habría curado a una endemoniada ${ }^{142}$.

Pero el máximo aprovechamiento de la retórica sacralizadora propiciada en el siglo XIII habrá de producirse mucho tiempo después, en un contexto particularmente conflictivo en el que la monarquía se hallaba especialmente necesitada de referentes legitimadores de toda índole. Cuando, en las Cortes de Olmedo de 1445, Juan II trata de recordar a los reunidos las obligaciones que tienen respecto de la monarquía y la incuestionabilidad que debe caracterizar a ésta, justamente en los días inmediatos a la batalla

\footnotetext{
${ }^{140}$ Nieto SORIA, Sancho IV. pp. 53-57.

141 "Asi como facemos agora los cristianos, que por la consagración se facen los sacerdotes é los obispos é los arzobispos é los reyes que son sagrados é coronados". Castigos, cap. X, $\mathrm{BAE}, \mathrm{p}$. 109. El texto, no obstante, resulta de lo más ambiguo, no pareciendo que se pueda alegar como prueba decisiva de que Sancho IV hubiera sido ungido ceremonialmente, aunque sí, en cambio, a mi modo de ver. de aprovechamiento de la ideología del origen divino para procurarse rasgos sacralizadores.

${ }^{1+2}$ Citado y valorado por primera vez por Marc BLoCH, Les rois thaumaturges. Etudes sur le caractère surnaturel attribué à la puissance rojale particulièrement en France et en Anglaterre, reed. París, 1983, p. 152, nota 1.
} 
de Olmedo, en donde la realeza castellana se jugaba su futuro a cara o cruz, el fundamento argumental básico que se alegará será la Segunda Partida. El texto de estas Cortes, de extraordinaria trascendencia política, es, ante todo, un resumen de la Segunda Partida, en donde se veía plasmada toda la imagen autoritaria y de incontestabilidad, en buena parte basada en la idea de origen divino de la realeza, que la monarquía pretendía dar en aquellas horas de agobio. Pues bien, en ese texto se resume con toda claridad el mensaje central de esta ideología, a la que el pensamiento alfonsino había dado base suficiente, de la que se podían extraer consecuencias sacralizadoras para el poder regio de unos monarcas que no pasaban por ceremonia pública de unción de ninguna especie. Así puede leerse: "E asi mesmo pospuesta la ley deuinal, la qual espresamente manda e defiende que ninguno non sea osado de tocar en su rrey e prinçipe commo aquel que es ungido de Dios nin aun de rretraer nin de dezir del ningunt mal nin aun lo pensar en su espiritu, mas que aquel sea tenido commo vicario de Dios e onrrado commo por esçelente e que ningunt non ssea osado dele rresistir, porque los que al rrey rresisten son vistos querer rresistir ala ordenança de Dios"143. Teniendo en cuenta que en las versiones, aunque tardías, conservadas de la Segunda Partida nada se dice del rey ungido, habrá que pensar que en este punto se hizo incorporación de lo desarrollado con relación a la unción regia y al carácter sacrílego de la resistencia al rey en la Primera Partida.

Pero este texto de Cortes no iba a ser un episodio aislado ${ }^{144}$, a partir de entoncts, la referencia al rey castellano como ungido de Dios será un lugar común, no exento de utilización política concreta ${ }^{145}$, dirigiéndose un intelectual del relieve de Rodrigo Sánchez de Arévalo al rey castellano como Vuestra Sacra Magestad ${ }^{146}$. Así, el impulso de la ideología política de la realeza alfonsina, en su proceso de secularización, es decir, de reinterpretación de referencias teológicas susceptibles de ser incorporadas a la construcción de un modelo monárquico con amplias pretensiones

\footnotetext{
${ }^{14 .}$ Cortes de los antiguos reinos de León y de Castilla, III, Madrid, 1866, p. 458.

${ }^{144} Y$ a he dado en diversas ocasiones testimonio de la utilización del apelativo "rey ungido" referente al monarca castellano a partir de Juan II. Así puede verse en Fundamentos ideológicos, pp. 64-65 e Iglesia y génesis del Estado moderno en Castilla, pp. 190-193.

${ }^{1+5}$ Tal como sucedió en 1465, cuando Enrique IV se dirigió al papa Paulo II, solicitando su amparo, ante la revuelta nobiliaria. Véase en Memorias de don Enrique IV de Castilla, II, Madrid, 1913, p. 498.

${ }^{1+6}$ Vergel de Príncipes, BAE, CXVI, p. 311.
} 
autoritarias, desembocaba en el siglo XV en el concepto de señorio $o$ monarquía divinal, tal como enunciarán los colaboradores de los monarcas trastámara en el trascurso del siglo $\mathrm{XV}^{147}$.

\section{LA IGLESIA EN LA ESTRUCTURA POLÍTICA}

Para la época bajomedieval, el proceso de transformación experimentado por el poder monárquico está estrechamente conectado con el problema de las relaciones con la Iglesia, tanto en el ámbito del propio reino, como del pontificio, siendo el siglo XIII un momento muy relevante en la evolución de estas relaciones que tienden a complejizarse como consecuencia de las nuevas pretensiones políticas de los príncipes que acaban afectando de lleno a la Iglesia ${ }^{148}$. Tal como se ha apuntado en alguna ocasión ${ }^{149}$, esta afectación de las relaciones entre monarquía e Iglesia por lo que fueron los cambios profundos en la estructura política se refleja, sobre todo, en dos niveles: legitimidad.

1) El de la formación de un espacio laico, poseedor de su propia

2) La constitución de una Iglesia nacional.

Mientras que la segunda de estas manifestaciones representa una tendencia muy característica de tiempos más tardíos, sobre todo referibles a los siglos $\mathrm{XV}$ y $\mathrm{XVI}^{150}$, la primera sí es claramente rastreable en sus orígenes en el siglo XIII.

\footnotetext{
147"Ya sabéis que los reyes reynan en lugar de Dios sobre la tierra; e porque así se representa su señorío divinal, todos los súbditos débenles fidelidad", Diego ENRÍQUEZ DEL CASTILlo, Crónica de Enrique IV. BAE, LXX, p. 103.

${ }^{1+8}$ Precisamente el carácter particularmente turbulento de las relaciones entre monarquía y pontificado. siempre con la referencia obligada al caso francés, durante la época de Felipe IV ha sido considerado tradicionalmente como una manifestación muy característica de las tendencias secularizadoras experimentadas por el poder monárquico, tal como ya observase Georges de LAGARDE. Así, señala que, si bien resultaría falso considerar que en el siglo XIII el espíritu de resistencia o de rebelión haya sido la tendencia principal de la sociedad laica, es. en cambio, cierto que, en reacción contra una influencia sin cesar creciente del clero y de las instituciones creadas por él, estallan profundos conflictos en ámbitos distintos y bajo formas diversas, de manera que los inevitables y tradicionales conflictos de la Iglesia con los príncipes toman a menudo en el siglo XIII nuevos matices (LAGARDE, op. cit., 159).

${ }^{1+9}$ BADIE, art. cit., pp. 213 y ss.

${ }^{150}$ Así puede verse, para una perspectiva general, en J.A.F. THOMSON, Popes and Princes, 1417-1517. Politics and Policy in the Late Medieval Church, Londres, 1980.
} 
En el caso de Castilla, esa formación de un espacio laico, poseedor de su propia legitimidad, no provocó niveles conflictivos del alcance de los ya conocidos en el caso francés, a fines del siglo XIII, aunque tal proceso experimentó un cierto impulso, sin suponer una eliminación de la presencia eclesiástica en el ejercicio del poder político, pero sí implicando una cierta apropiación por el poder real de una legitimidad particular a la que se intenta evitar dependencias excesivas de lo eclesiástico, procurando, además, la potenciación de mecanismos de control sobre el clero. En concreto, hubo toda una serie de cuestiones en las que cabe advertir indicios de tal tendencia, en particular, las siguientes:

1) La función legitimadora de la Iglesia en el acceso del rey al trono.

2) La enunciación y desarrollo por el poder real de una ideología en la que se definía el modelo de relaciones con la Iglesia.

3) La consolidación de los grandes prelados en las funciones políticoadministrativas.

4) El compromiso político del episcopado y del papado en los contextos de conflicto político.

5) Los indicios de anticlericalismo con significación política.

1) Páginas atrás se señalaban las implicaciones que la interpretación de la ideología del origen divino de la realeza tenía con respecto a la posición en que quedaban los eclesiásticos en la función de legitimación del rey en el contexto del acceso al trono, poniendo de relieve cómo la vinculación directa de la realeza con la divinidad y su búsqueda de autonomía con respecto a poderes de posible intervención limitadora, como el eclesiástico, dio lugar, entre otras circunstancias allí valoradas, a evitar ceremonias que pudieran plasmar alguna función clerical de control sobre la realeza o de mediación entre el rey y la divinidad. Por tanto, con relación a este problema, el ceremonial, se puede afirmar que predominó, si así se prefiere decir, un criterio decididamente secularizador, como no podía ser de otro modo, si se tienen en cuenta los rasgos ideológicos del proyecto político alfonsino. Todo ello, en cambio, no impidió que, con motivo de la entronización de Sancho IV, hubiera particular intervención eclesiástica que, seguramente, habrá que poner en relación con las especiales circunstancias políticas bajo las que se produjo tal acontecimiento.

2) Por otra parte, dentro del discurso ideológico general de la realeza, las relaciones con la Iglesia ostentaron un lugar destacado, quedando 
definidas, en dicho discurso ideológico, a partir de tres principios bási$\cos ^{151}$. En primer lugar, un compromiso de protección del rey hacia la Iglesia, como consecuencia de su posición de defensor natural que le imponía la propia idea de vicariato divino y que debía traducirse en una actuación militar de significación religiosa, en un amparo de los privilegios, franquezas y libertades eclesiásticas y en un apoyo económico en forma de otorgamiento de nuevas donaciones y privilegios. En segundo lugar, estaba el principio de intervención real en materia eclesiástica, no exento de traducción legal ${ }^{152}$, y para el que, desde la monarquía, se encontraban justificaciones tanto relativas al origen del poder real como a los méritos contraídos por los monarcas castellanos en su lucha contra el infiel, de lo que se deducían derechos de intervención para el rey que éste trató de proyectar hacia los temas clave de la jurisdicción eclesiástica, la fiscalidad y la promoción de los clérigos. Finalmente, estaba el principio de relación armónica y de mutuo apoyo, gráficamente plasmado por la imagen de los Castigos con la referencia al cuchillo temporal y al espiritual que debían acudir en mutua ayuda ${ }^{153}$. Con todo ello, la Iglesia quedaba encuadrada en el proyecto político de la monarquía, dentro de lo que se presentaba como un esquema ideal de relaciones coherente con esa tendencia a definir un espacio temporal laico poseedor de su propia legitimidad, no carente de presencia eclesiástica, pero controlada por la propia realeza.

3) La presencia de los prelados más destacados del reino en los medios cortesanos y asumiendo funciones político-administrativas para la realeza tendió a consolidarse ${ }^{154}$. Los monarcas lo entendieron como un factor de legitimación de su propio poder contar entre sus consejeros y colaboradores inmediatos a algunos de los prelados más influyentes. No obstante, hay que tener en cuenta que esta presencia estuvo controlada por la monarquía, desde la que se decidió quiénes debían ostentar estas funciones como consecuencia, por lo general, de las afinidades personales con el propio monarca. Por ello, tal hecho no debería valorarse como expresión de

\footnotetext{
${ }^{151}$ Esta es una cuestión que ya traté más por extenso en mi Iglesia y poder real, pp. 21-25, donde remito para mayores precisiones.

${ }^{152}$ Así, por ejemplo, la normativa relativa a las elecciones episcopales, en las que se otorgaba al monarca una cierta función en su desarrollo, tal como puede verse en Partidas. I, V. 18 .

${ }^{15 .}$ Castigos, cap. XVI, BAE, pp. 122-123.

${ }^{154}$ Este asunto ya lo traté por extenso para esta época en mi Iglesia y poder real, pp. 27-62.
} 
una especie de derecho o privilegio eclesiástico, sino más bien como una conveniencia de los monarcas, puesto que, con ello, a la vez que ponían a su directo servicio personajes, a veces, muy competentes y bien preparados, establecían un medio de relación inmediata con la Iglesia del reino y contribuían a aproximar la imagen de su corte a los ideales propios de una monarquía de origen divino, correlato de la corte celestial ${ }^{155}$.

4) Desde la monarquía, desde luego, no se dudó que el episcopado, como, en otro nivel, el papado, eran factores de significación política y, por ello, se consideró necesario implicarlos en las situaciones de confrontación y propiciar su compromiso político favorable a los intereses del poder regio. Sin embargo, en este punto hay que observar que el episcopado, habitualmente, ante las circunstancias de conflicto político, se dividió, resultando prácticamente imposible alcanzar el consenso; actuando cada prelado, al igual que sucedía con la nobleza, en función de criterios particulares que dejaban los deberes de lealtad hacia el rey en un plano secundario ${ }^{156}$.

Por otra parte, por lo que se refiere al pontificado ${ }^{157}$, la confrontación entre príncipes y papas se ha planteado tradicionalmente como un rasgo muy característico del impulso del espíritu laico en el contexto del siglo XIII, sobre todo, durante su segunda mitad. Las circunstancias favorables a la tensión entre el papa y los reyes castellanos fueron, en este periodo, bien abundantes, desde la actitud pontificia contraria a la candidatura castellana en el fecho del imperio, siguiendo por las sinuosas relaciones que caracteri-

\footnotetext{
${ }^{155}$ En Castigos e documentos del rey don Sancho se alude con cierto detenimiento a la figura de los prelados y los religiosos (caps. XVI y XVII), aconsejando al futuro rey la especial consideración que hacia ellos debe tener el buen monarca, pareciendo dar pie a que otorgue a los prelados destacada presencia junto al rey: "Otrosí, mio fijo, págate mucho de los perlados é ámalos, que oficiales son de Dios é su lugar tienen en lo espiritual, é aun dellos hay que en lo corporal tambien, por gracias que les fecieron los reys é los emperadores é los príncipes é señores de la tierra". Seguidamente. se dan algunas razones del porqué la presencia de prelados junto al rey y cómo a éste la puede convenir que así sea a fin de ofrecer una imagen más creíble de rey cristiano: "Et como quier que de todos (los prelados) te pagues, señaladamente te paga de aquellos que mejor viven é mejor mantienen su estado, é mas á servicio de Dios; que por tales como aquestos habiendo tú vida é facimiento con ellos, guiará Dios por ello bien la tu alma é la tu carne é los tus fechos, á habrás fama de buen christiano" (BAE, cap. XVI, p. 122). Sin embargo, el resto del texto dedicado a esta cuestión en lo que abunda es en las buenas costumbres que cabe esperar del buen prelado y del buen religioso, tratándose más de una especie de espéculo de clérigos que de una justificación de su protagonismo político.

${ }^{156}$ Así puede constatarse para los diversos episodios de conflicto político, tal como ya traté en mi Iglesia y poder real. pp. 76-92.

${ }^{157}$ Amplio análisis de los asuntos más significativos que afectaron a las relaciones entre reyes y papas en: Peter Linehan, La Iglesia española y' el Papado en el siglo XIII, Salamanca, 1975.
} 
zaron buena parte del reinado de Sancho IV, primero con motivo de la postura del papado durante la guerra civil, favorable a Alfonso X, y luego como consecuencia de la ansiada bula de legitimación para el matrimonio con María de Molina. Sin embargo, desde la monarquía se tendió evitar las rupturas totales ${ }^{158}$. Alfonso $\mathrm{X}$ aceptó, a pesar de todas sus reservas, la resolución en su contra de Beaucaire, quizá porque coincidió con un momento de particular necesidad del apoyo pontificio para lo que era el nuevo problema de frontera surgido tras la invasión meriní ${ }^{159}$. Del mismo modo, el apoyo pontificio para las empresas de la frontera, junto con la nunca perdida esperanza de que el papa acabase accediendo a la legitimación de su matrimonio, hicieron soportables los no pocos desaires recibidos por Sancho IV de la sede romana ${ }^{160}$.

Todo ello, en definitiva, apunta a que las relaciones de los monarcas castellanos con el pontificado eran lo bastante complejas, presentando la suficiente variedad de frentes, como para que el desacuerdo con relación a un asunto, por decisivo que éste fuera, no cerrase las posibilidades de coincidencia en otro. Por esto, si el criterio del espíritu laico pudo justificar determinadas reivindicaciones regias con respecto al pontificado que afectaron, sobre todo, a las relaciones cotidianas con la Iglesia de su reino y a sus pretensiones de mayor control sobre la misma, así como a la evitación de una dependencia excesiva con relación a la legitimidad del poder real, ese mismo criterio de espíritu laico no resulta suficiente para explicar enteramente el sentido de las relaciones entre pontífices y monarcas, en las que el pragmatismo de lo inmediato, en muchas ocasiones, hacia postergar pretensiones ideológicamente significativas de más amplio alcance a largo plazo.

5) A pesar de lo que se acaba de señalar con respecto a la postura regia, no parece que se pueda negar la presencia de ciertos indicios de anticlericalismo expresados, sobre todo, por los procuradores de las ciudades castellanas en Cortes. Se ha llamado la atención sobre la posible sincroniza-

\footnotetext{
${ }^{158}$ Se ha llamado la atención sobre el hecho de que la imagen negativa y crítica que del papado suele reflejarse en las Cortes de Castilla no se detecta hasta el siglo XIV, ya en tiempos de Alfonso XI: Ana ARRANZ Guzmán, La imagen del pontificado en Castilla a traiés de los Cuadernos de Cortes, "Hispania Sacra", 42 (1990), pp. 721-760.

${ }^{159}$ Véase al respecto: Carlos de Ayala Martínez, Alfonso X: Becuccaire y el fin de la pretensión imperial, "Hispania", XLVII (1987), pp. 5-31.

${ }^{16()}$ NIETO SORIA, Sancho IV, pp. 50, 68-71 y 106-108.
} 
ción entre los enfrentamientos entre concejos y poderes eclesiásticos con el reflejo de denuncias anticlericales en Cortes ${ }^{161}$. Ello apuntaría a considerar que, más que un fenómeno genérico de anticlericalismo, quizá ocasionalmente detectable, estaríamos predominantemente en presencia de la confrontación entre poder concejil y poder episcopal, entre los que se darían inevitables confrontaciones locales, sobre todo con motivo de las atribuciones señoriales de los obispos, repercutiendo tal hecho en las demandas planteadas en Cortes $^{162}$.

Caso particularmente relevante para el problema del ejercicio del poder real, en el que se puso de manifiesto la oposición de los procuradores de las ciudades al protagonismo político del clero, fue el que se planteó en las Cortes de Valladolid de 1295 , ya fallecido el rey don Sancho ${ }^{163}$. Allí se demandó que los clérigos que estaban cumpliendo funciones políticoadministrativas y cuya presencia no estuviera justificada por razones de servicio religioso, abandonasen la corte ${ }^{164}$. No era ciertamente la primera vez que esto se planteaba, pues ya hubo pronunciamientos en el mismo sentido en las Cortes de Valladolid de $1258^{165}$. Sin embargo, tanto en un caso, como en el otro, se plantea idéntica petición con respecto a los ricoshombres, a la vez que se reivindica mayor presencia política para los hombres buenos de las ciudades. Por ello da la impresión de que estamos, una vez más, ante fenómenos reivindicativos de las oligarquías urbanas representadas en Cortes en función de intereses propios, más que ante un movimiento encuadrable en alguna forma de anticlericalismo.

Todo lo que se acaba de considerar con relación a la Iglesia apuntaría, en cualquier caso, a la voluntad regia, tal como se decía al principio de este apartado, de crear espacios de legitimidad autónoma, no dependiende de la mediación eclesiástica, lo que no obstaculizaba el

\footnotetext{
${ }^{161}$ Ana ARRANZ GuZMÁN, Los enfrentamientos entre concejos y poderes eclesiásticos en las Cortes castellanas: ¿sincronización de los conflictos?, "Hispania", 171 (1989), 5-68.

${ }^{162}$ Tal enfoque tiene una plasmación muy característica en el conflicto entre abadengos y realengos, frecuentemente reflejado en Cortes, tal como puede verse en Ana ARRANZ GUZMÁN, El tercer estado castellano ante las relaciones realengo-abadengo, siglos XIII-XV, "Hispania", 172 (1989), pp. 443-476

${ }^{163}$ Referencia a tal asunto en: Peter LineHan, Ecclesiastics and the Cortes of Castile, en "Las Cortes de Castilla y León en la Edad Media", II, pp. 131-135. 132.

${ }^{164}$ Cortes de los antiguos reinos de León y Castilla, I, Madrid, 1861, pets. 2, 4 y, pp. 131-

${ }^{165}$ Ibid. p. 58, pet. 16 .
} 
desempeño de una presencia eclesiástica en la vida política que se pretendía controlada en todas sus claves, aunque no fuera siempre así, desde la realeza. Todo ello tenía lugar a la vez que se impulsaba una ideología regia de claras connotaciones intervencionistas en materia clerical, justificándose desde los criterios propios del origen divino de la realeza. La disonancia planteada con respecto a algunos de estos rasgos por los concejos no era tanto la consecuencia de una forma de anticlericalismo, como, sobre todo, la plasmación de las tensiones cotidianas a las que las oligarquías urbanas debían hacer frente y que situaban en planos similares sus relaciones de conflicto con los representantes de la alta nobleza como con los del episcopado.

\section{ALGUNOS TÓPICOS HISTORIOGRÁFICOS}

Tal como se ha podido ver a partir de las consideraciones precedentes, parece evidente la presencia de algunos indicios relacionados con la concepción o con el ejercicio del poder real englobables en lo que tradicionalmente suele definirse como espíritu laico o como formas secularizadoras, entendiéndose, por tanto, como fórmula de liquidación o de postergamiento de fundamentos legitimadores de origen teológico, sagrado, religioso o clerical. No obstante, tal hecho no está exento de contradicciones y de límites, pues ni define en su totalidad las tendencias observadas por el poder real, ni, en segundo lugar, experimenta una progresiva potenciación en el tiempo.

En primer lugar, no define en su totalidad las tendencias observadas por el poder real, pues no faltan aquéllas que contradicen lo que cabría entender como fenómenos típicamente secularizadores. Así, por ejemplo, el mantenimiento del protagonismo clerical en los actos de gobierno, la utilización de referentes legitimadores de orden teológico, la poderosa persistencia de la tradición doctrinal cristiana como inspiradora de ideales políticos... Del mismo modo, tampoco hay una progresiva potenciación en el tiempo de esas tendencias secularizadoras, advirtiéndose avances y retrocesos en el marco cronológico considerado que, con frecuencia, es posible poner en relación con acontecimientos concretos de crisis de legitimidad de alguna pretensión regia.

Ha señalado Jacques Le Goff cómo las formas más impresionantes de la propaganda se enraizan en lo sagrado, de modo que el Estado, lejos de 
proceder de un proceso de laicización, de desacralización del poder, tal como frecuentemente se afirma, recibe la trasferencia de lo sagrado desde el poder espiritual al temporal, siendo esto lo que Kantorowicz denominó como los misterios de estado, teniendo siempre en cuenta la variedad de matices que encierra el concepto sagrado, que pertenece - siguiendo con la línea argumental de Le Goff - tanto al universo de lo religioso como al vocabulario político ${ }^{166}$.

Es aquí donde, a partir de todo lo analizado, conviene señalar alguna precisión conceptual con relación a la idea de secularización, a fin de darle operatividad histórica en el contexto de la época bajomedieval y eliminar de ella lo que tiene de tópico historiográfico desde el que se dificulta la aproximación a los problemas concretos que plantea la evolución del poder real como ideología y como proyecto político.

Si por secularización, a la vez que se entiende un proceso esencial en la evolución de las monarquías bajomedievales hacia fórmulas más complejas y eficaces de poder político, se considera aquella tendencia a la sustitución de fundamentos de legitimidad de origen teológico y religioso por otros de índole plenamente secular y de los clérigos por los laicos en determinadas funciones gubernativas, estamos ante un tópico carente de eficacia historiográfica. Sólo - tal como se acaba de apuntar más arriba a partir de la opinión de Le Goff- como fórmula de trasposición de referencias elaboradas en el plano de lo teológico, de lo religioso, de lo sagrado y de lo eclesiástico hacia lo que es el plano del ejercicio y la definición conceptual del poder real puede ser valorable como factor ciertamente relevante en lo que fue la transformación bajomedieval de los sistemas monárquicos. Desde este enfoque, los clérigos, no sólo no son borrados del sistema político, sino que son integrados en el mismo, tendiéndose a sistematizar su presencia, ciertamente más selectiva y de forma cuantitativamente menos relevante, pero no por ello necesariamente menos

\footnotetext{
${ }^{160}$ Jacques LE GOFF, conclusiones a Le forme della propaganda politica nel due e nel trecento, pp. 520-521. Continua desarrollando la idea que acabo de resumir a partir de la referencia a algunos ejemplos: "Une notion comme celle de 'paradis' témoigne de ce transfert du sacré à la vie publique. Le 'Liber Paradisus' de Bologne place un acte politique sous le patronnage du paradis, un lieu de célebration politique comme la place de la cathédrale reçoit le nom de 'Paradisus ecclesiae': c'est un espace, un jardin sacré. Albert le Grand, dans une série de sermons prononcés à Aubsbourg dans les années 1260, qui constituent un véritable traité de théologie urbaine, compare les rues de la ville à l'enfer et ses places au paradis. Les liens entre propagande et sacré sont particulièrement forts et clairs dans le cas des prophéties politiques et des expressions eschatologiques des programmes politiques".
} 
influyente, a la vez que también se desarrollan fórmulas que permitan la integración sistemática de la Iglesia del reino en su conjunto en las estructuras gubernativas dependientes del poder monárquico, en orden a su mejor control por éste.

Planteada la cuestión en estos términos, estamos ante la compatibilidad entre secularización, por un lado, y teologización, divinización, sacralización y clericalización del poder real, por otro lado. Precisamente, el que se haya producido tal compatibilidad lo que demuestra es que todas estas fórmulas no fueron otra cosa que una de las varias respuestas que, desde el poder real, se dio al problema de la construcción de un centro político, cuyo titular era el monarca, en el marco de una sociedad caracterizada por unas relaciones de poder básicamente definidas por la sucesión de alianzas y confrontaciones de importantes fuerzas centrífugas, con intereses propios definidos, sometidas a continuas divisiones internas y en continuo realineamiento con respecto al propio poder real.

En Castilla, en el trascurso de la segunda mitad del siglo XIII, se había elaborado una representación ideológica del rey y del poder real que, a partir de un enfoque teocéntrico, producía un efecto propagandístico de sacralización del soberano y de la monarquía, sin que en ello tuviera el clero función mediadora alguna mediante instrumentos ceremoniales. Probablemente era difícil una pretensión secularizadora -en el sentido que hemos apuntado más arriba - de mayor calibre. Los tiempos venideros habrían de demostrar la utilidad política del procedimiento.

Por contra de la preocupación de algunos autores tratando de precisar la ortodoxia o heterodoxia de la realeza bajomedieval castellana y, por extensión, de las hispánicas, midiendo la aproximación o alejamiento con respecto a prácticas litúrgicas de sacralización,cuando ya en el siglo XIII se dudaba por algunos de su eficacia espiritual y de su conveniencia política, o a la exhibición de unos símbolos u otros, me parece que la cuestión políticamente relevante, en el plano de la confrontación ideológica que supuso el proceso de transformación al que se vio sometido la realeza desde mediados del siglo XIII, está en otro lugar. Tal cuestión se encuentra, en primer lugar, en la contextualización en el marco del conflicto entre poder real y fuerzas centrígugas del autoconcepto que la monarquía trató de impulsar. En esa perspectiva lo que sí podía tener peso, fuera con unos símbolos o con otros, con unas ceremonias o con otras - cuestiones todas ellas muy importantes como medios de comunicación, pero no como elementos de caraterización sustancial- era el que el rey se pudiera 
presentar como vicario de Dios que actuaba en su nombre y a su semejanza, deduciendo de ello toda una serie de atributos y de competencias que se pretendían incontestables, teniendo como consecuencia que la rebelión de un natural pudiera considerarse no sólo como un delito, sino como un acto sacrílego en su sentido estricto, es decir, como un acto contra sagrado. Y digo que esto es lo verdaderamente importante porque, ante la novedad de sus pretensiones, el poder real era consciente, y cada vez más, según se fueron sucediendo los acontecimientos - Alfonso $\mathrm{X}$ fue todo un ejemplo en ese proceso de toma de conciencia-, de que la reacción de esas fuerzas centrífugas era inevitable, y cuanta más experiencia tuvo de la dimensión de esa reacción y más se reafirmó el poder real en esas pretensiones de carácter autoritario, más valoró todos los beneficios que podía obtener de la interpretación política de determinados conceptos vinculados a la idea de lo teológico, de lo sagrado, como también de lo jurídico y de lo histórico y de su integración en su sistema global de representación.

Naturalmente, para abordar la interpretación de este tipo de problemas conviene evitar la presencia de modelos preconcebidos referidos a casos concretos, cuyo carácter modélico, a mi modo de ver, queda invalidado por su propia rigidez. La historia comparativa no puede abordarse con éxito, es decir, con capacidad de explicación, a partir de la simple comprobación de lo que es igual, parecido o distinto en un lugar o en otro, sino a partir de la voluntad de tratar de comprender si lo que ocurre distinto en diferentes lugares puede tener coherencia o explicación dentro de un mismo sistema de civilización que admite, tal como sucedía en la Europa bajomedieval, opciones diversas. De lo contrario, la otra opción habrá de ser, tal como parece proponerse por parte de algún autor con relación al caso hispánico, pues se refiere al conjunto hispánico, no sólo a Castilla, la creación para éste de una categoría socio-cultural particular, ante lo que se presenta como adicalmente diferente con respecto a los modelos occidentales ${ }^{167}$.

\footnotetext{
167" Ni unción, ni consagración, ni coronación. ni poderes milagrosos de curación, ni siquiera panteón real: obviamente los fundamentos de la realeza en la España medieval no pertenecen al mismo ámbito cultural y social en los que florecieron estos ritos y gestos. fundadores del poder de los reyes de Francia e Inglaterra". En RUCQuOI, De los reves que no son taumaturgos. p. 78. En función de esta apreciación. parece ser necesaria según la autora, la enunciación y caracterización de un ámbito cultural y social particular para el espacio hispánico. en el que se plasme toda la distancia existente con respecto al modelo occidental representado por las realezas inglesa y francesa. En primer lugar. pongo en duda que los rasgos enumerados sean verdaderamente los fundamentos de la realeza en parte alguna. en todo caso, serán medios de propaganda y de comunicación de lo que. en cambio. sí debe ser considerado como el
} 
Señalaba Le Goff su voluntad de distinción de diversos conceptos como el de lo sagrado, lo religioso, lo eclesiástico y lo taumatúrgico, para mostrar cómo estos diferentes elementos formaron un sistema articulado que caracterizó un campo semántico del poder real y de sus representaciones en la Francia medieval ${ }^{168}$. Pues bien, he pretendido ofrecer algunas reflexiones sobre cómo, también en el caso castellano, todos estos elementos contribuyeron a definir un sistema de representación del poder regio, ciertamente distinto en su globalidad del estudiado por Le Goff, pero enfocado a partir de la interpretación particular de unos problemas y de unos instrumentos para su resolución comparables, como no podía ser de otro modo, teniendo en cuenta todos los factores en juego. No tengo la impresión de que las soluciones adoptadas por la realeza castellana, aunque propias $y$, por tanto, con sus rasgos particulares, resulten ajenas al patrimonio intelectual, ni a la problemática política de fondo en que se incardinaron las transformaciones políticas experimentadas por las realezas occidentales, entre ellas, además de la castellana, la aragonesa, la navarra o la portuguesa, desde cuyo estudio, también habría mucho que decir, si el objetivo de la investigación fuera, tal como no estaría demás plantearse, establecer modelos comunes de análisis realmente eficaces y no simplificadamente reduccionistas y, por ello, útiles tan sólo para unos pocos casos concretos o para distinguir lo supuestamente modélico de lo supuestamente anómalo.

\section{RÉSUMÉ}

Une idée très répandue c'est de considérer le XIIIe siècle comme le moment où se produit la tendance à la sécularisation des fondements idéologiques du pouvoir politique. Cette

\footnotetext{
fundamento ideológico esencial del poder real tal como se concibió en Francia e Inglaterra, como también, por cierto, en las monarquías hispánicas: el origen divino del poder real, con todas sus consecuencias, en cuanto a la concepción del poder. Con respecto a los demás rasgos distintivos enumerados por la autora remito a lo ya considerado en éste y en otros trabajos míos Finalmente, con respecto a la ausencia de panteón real, que no ha sido objeto aquí de tratamiento, supongo que su ausencia en el caso hispánico será consecuencia de que, una vez más, el establecimiento de un modelo de panteón real de inspiración francesa, entorpece la calificación de tales para los hispánicos. De cualquier manera, confío en que esta particular exigencia no sea razón suficiente para negar la condición de panteones reales a lugares como San Isidoro de León, Reyes Viejos y Reyes Nuevos de Toledo, Cartuja de Miraflores, Capilla Real de Granada o monasterio de Poblet, entre otros. 19.

${ }^{168}$ LE GofF, Aspects religieux et sacrés de la monarchie française du Xe au XIIIe siècle, p.
} 
tendance, cependant, est compatible avec la permanence de la croyance en l'origine divine du pouvoir royal comme noyau essentiel de l'idéologie politique de la royauté.

Cette étude se propose de préciser le rôle joué par les deux questions à propos de tout le processus de redéfinition subi par le projet politique de la royauté castillane, en analysant ses diverses implications et en attachant une attention spéciale à une de ses phases décisives, comme celle qui eut lieu au cours du règne d'Alphonse $\mathrm{X}$ et, dans une moindre mesure, de celui de Sanche IV.

\section{SUMMARY}

It is a widely held view that the XIII Century was the moment when the tendancy arose to secularize the ideological bases of political power. However, this tendancy is compatible with the continued belief in the divine right of kings as the esential nucleus of the political ideology of royalty.

The intention of this study is to determine the role that both questions played in relation to the whole process of redefinition suffered by the political projection of Castilian royalty, analyzing its various implications and with special emphasis on one of its decisive phases, such as took place during the reign of Alfonso $\mathrm{X}$ and, to a lesser degree, of Sanche IV. 